\title{
Simple tertiary phosphines to hexaphosphane ligands: Syntheses, transition metal chemistry and their catalytic applications
}

\author{
MARAVANJI S BALAKRISHNA*, SOWMYA RAO and BIMBA CHOUBEY \\ Department of Chemistry, Phosphorus Laboratory, Indian Institute of Technology Bombay, \\ Mumbai 400 076, India \\ e-mail: krishna@chem.iitb.ac.in
}

\begin{abstract}
Designing efficient phosphorus-based ligands to make catalysts for homogeneous catalysis has been a great challenge for chemists. Despite a plethora of phosphorus ligands ranging from simple tertiary phosphines to polyphosphines are known, the enthusiasm to generate new ones is mainly due to the demand from industry for economical and robust catalytic system operational under normal atmospheric conditions. In this context, we have developed new synthetic methodologies for making unusual inorganic ring systems containing trivalent phosphorus centres, novel phosphorus-based multidentate and hybrid ligands and explored their rich transition metal chemistry and catalytic applications. We have also fine tuned a few existing ligand systems with donor functionalities to employ them in homogeneous catalysis. The details are summarized in this account.
\end{abstract}

Keywords. Phosphines; transition metal complexes; catalysis; carbon-carbon coupling reactions; hydrogenation reactions; multidentate ligands.

\section{Introduction}

The ceaseless curiosity in designing new types of phosphorus-based ligands is essentially due to their flexible coordination behaviour with both early and late transition metals and their applications in organic synthesis. ${ }^{1}$ The undeniable fact is that they provide colossal agility in the incorporation of a range of steric and electronic attributes at phosphorus atoms that in turn facilitates the generation of appropriate metal complexes which can promote homogeneous catalysis under mild conditions with remarkable turnover numbers. ${ }^{2}$

We have designed several phosphorus-based ligands ranging from simple monodentate to tri-, tetra- or hexadentate systems and also modified a few existing ligands with donor functionalities and explored their rich transition metal chemistry ${ }^{3}$ and catalytic applications. ${ }^{4}$ The details of our contributions are briefly summarized.

\section{10-Membered heterocyclic diphosphanes}

Bis(dichlorophosphino)aniline, $\mathrm{PhN}\left(\mathrm{PCl}_{2}\right)_{2}$ reacts with one equivalent of 2,2'-thiobis(4,6-di-tert-butylphenol) to afford a 10-membered heterocycle, $\mathrm{PhN}(\mathrm{PCl})_{2}$ $\left\{\left(-\mathrm{OC}_{6} \mathrm{H}_{2}\left({ }^{t} \mathrm{Bu}\right)_{2}\right)(\mu-\mathrm{S})\left(\left({ }^{t} \mathrm{Bu}\right)_{2} \mathrm{C}_{6} \mathrm{H}_{2} \mathrm{O}-\right)\right\}$ (1) in high yield (see scheme 1). The structure of the heterocycle 1 has been determined by a single-crystal X-ray

*For correspondence analysis. The 10-membered heterocycle 1 reacts with $\mathrm{SbF}_{3}$ to afford the corresponding fluoro derivative $\mathbf{2}$ in good yield. The compounds $\mathbf{1}$ and $\mathbf{2}$ act as tridentate ligands with molybdenum carbonyl derivatives forming complexes of the type, $\left[\mathrm{Mo}(\mathrm{CO})_{3}\left\{\eta^{3}-\mathrm{PhN}(\mathrm{PX})_{2}-\right.\right.$ $\left.\left\{\left(-\mathrm{OC}_{6} \mathrm{H}_{2}\left({ }^{t} \mathrm{Bu}\right)_{2}\right)(\mu-\mathrm{S})\left(\left({ }^{t} \mathrm{Bu}\right)_{2} \mathrm{C}_{6} \mathrm{H}_{2} \mathrm{O}-\right)\right\}\right](3, \mathrm{X}=\mathrm{Cl}$; $4, X=F)$. A crystal structure of the fluoro derivative 4 showed the facial tricarbonyl complex comprising of a relatively strain free tetracyclic structure with molybdenum in an octahedral environment coordinated to two phosphorus and sulphur atoms. ${ }^{5}$ The heterocyclic diphosphane 2 readily reacts with various transition metal derivatives exhibiting $\eta^{2}$ and $\eta^{3}$ modes of coordination as shown in scheme 2 .

\section{Transition metal derivatives of aminophosphines, $\mathrm{Ph}_{2} \mathrm{PN}(\mathrm{H}) \mathrm{R}\left(8, \mathrm{R}=\mathrm{Ph} ; 9, \mathrm{C}_{6} \mathrm{H}_{11}\right)$}

The reactions of aminophosphines, $\mathrm{Ph}_{2} \mathrm{PN}(\mathrm{H}) \mathrm{R}$ (8, $\left.\mathrm{R}=\mathrm{Ph} ; 9, \mathrm{C}_{6} \mathrm{H}_{11}\right)$ with $\mathrm{Pd}(\mathrm{COD}) \mathrm{Cl}_{2}$ lead to the $\mathrm{P}-\mathrm{N}$ bond cleavage to produce a chloro-bridged dimer, $\left[\mathrm{Pd}\left(\mathrm{PPh}_{2} \mathrm{O}\right)\left(\mathrm{PPh}_{2} \mathrm{OH}\right)(\mu-\mathrm{Cl})\right]_{2} \quad$ (10), whereas with $\mathrm{Pt}(\mathrm{COD}) \mathrm{Cl}_{2}$, disubstituted complexes, cis$\left[\mathrm{PtCl}_{2}\left\{\mathrm{PPh}_{2} \mathrm{~N}(\mathrm{H}) \mathrm{R}\right\}_{2}\right]\left(\mathbf{1 1}, \mathrm{R}=\mathrm{Ph} ; \mathbf{1 2}, \mathrm{C}_{6} \mathrm{H}_{11}\right)$ were obtained. The reaction of $\mathbf{8}$ or $\mathbf{9}$ with $\mathrm{K}_{2} \mathrm{PtCl}_{4}$ afforded the platinum complex, $\left[\mathrm{Pt}\left\{\left(\mathrm{PPh}_{2} \mathrm{O}\right)_{2} \mathrm{H}\right\}_{2}\right](\mathbf{1 3})$, via $\mathrm{P}-\mathrm{N}$ bond cleavage, as shown in scheme 3 . The ${ }^{31} \mathrm{P}$ NMR spectrum of 13 shows a single resonance at $53.4 \mathrm{ppm}$ with a ${ }^{1} J_{\mathrm{PtP}}$ coupling of $3958 \mathrm{~Hz}{ }^{6}$ 


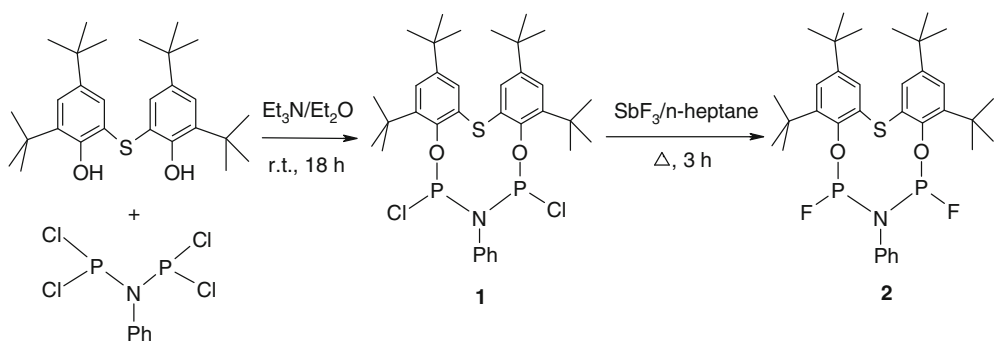

Scheme 1. Preparation and fluorination of heterocyclic diphosphane 1.

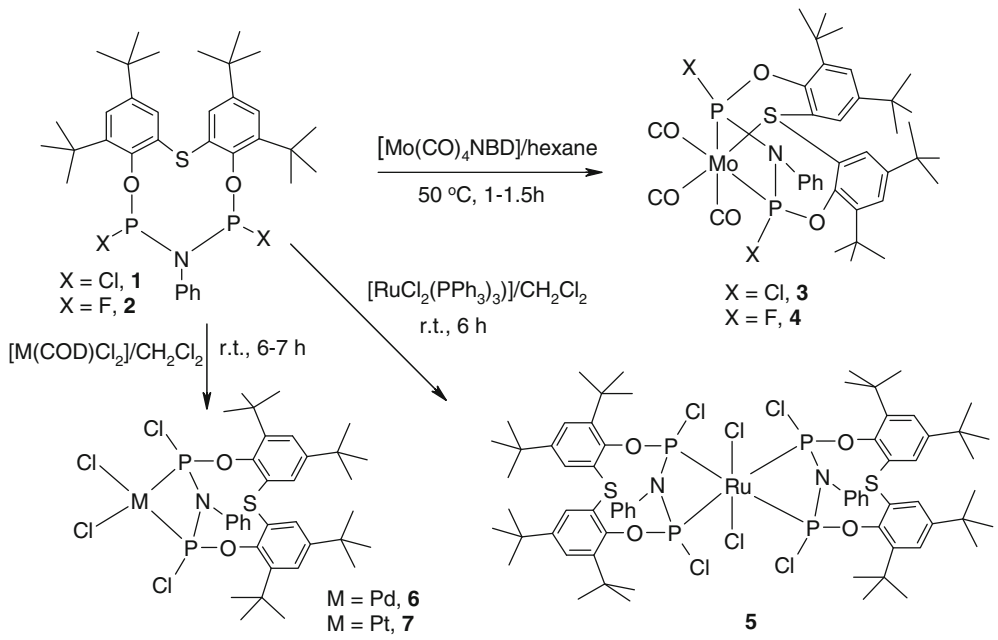

Scheme 2. Reactions of cyclodiphosphane 1.

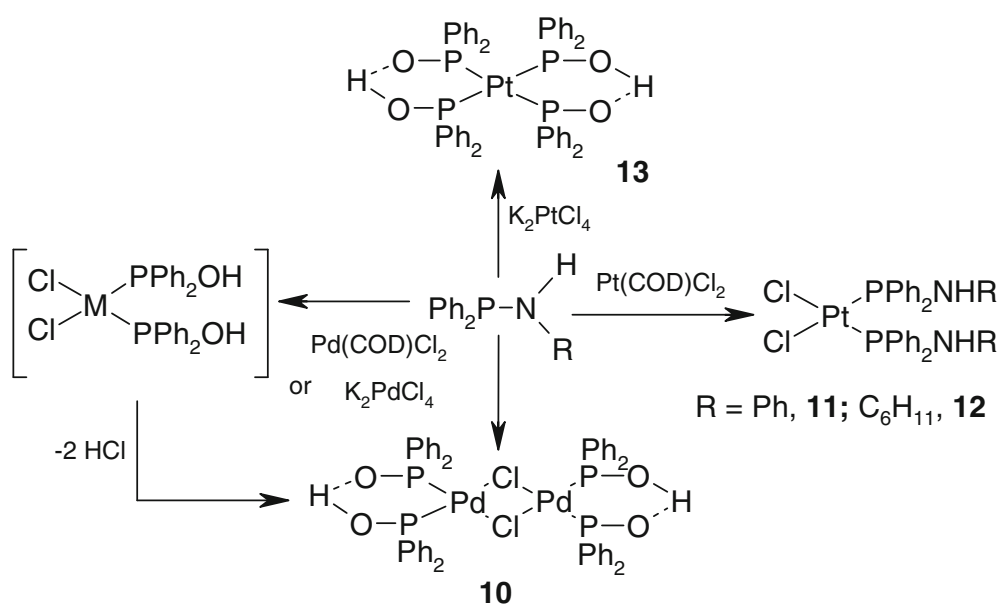

Scheme 3. Reactions of aminophosphine with $\mathrm{Pd}^{\mathrm{II}}$ and $\mathrm{Pt}^{\mathrm{II}}$ derivatives.

The reaction of 9 with either $\mathrm{RuCl}_{2}(\mathrm{DMSO})_{4}$ or $\mathrm{RuCl}_{2}\left(\mathrm{PPh}_{3}\right)_{3}$ in $4: 1$ molar ratio yielded the ionic complex, $\left[\mathrm{RuCl}\left\{\mathrm{Ph}_{2} \mathrm{PN}(\mathrm{H}) \mathrm{C}_{6} \mathrm{H}_{11}\right\}_{3}\right] \mathrm{Cl}$ (14). The ${ }^{31} \mathrm{P}$ NMR spectrum of $\mathbf{1 4}$ consists of a single resonance at $76.4 \mathrm{ppm}$ indicating the tetrahedral nature of the molecule and the mass spectrum of the complex showed a molecular ion peak (MS FAB: $986\left[\mathrm{M}^{+}\right]$) corresponding to the cationic species. The rare low-coordination of ruthenium in the molecule is attributed to the sterically demanding aminophosphine ligands. However, a trigonal bipyramidal geometry around the ruthenium(II) centre with two chlorides in axial positions and the three 


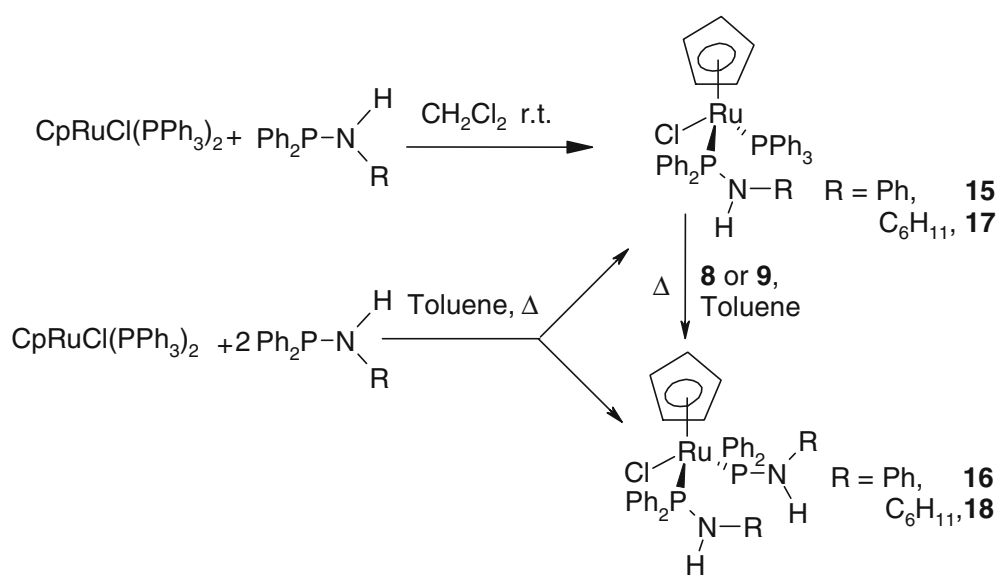

Scheme 4. Prepatation of ruthenium(II) complexes 15-18.

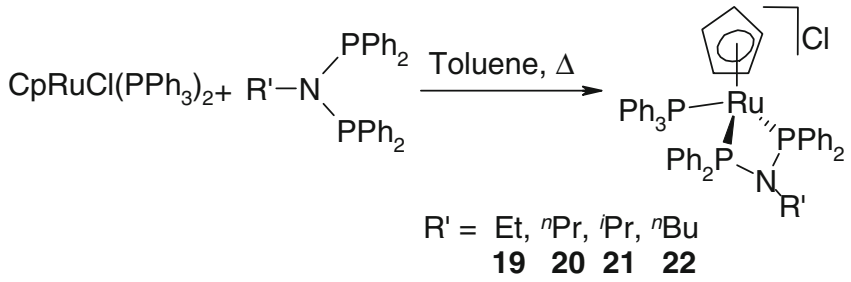

Scheme 5. Preparation of ruthenium(II) cationic complexes 19-22.

phosphorus centres in the trigonal plane could not be ruled out as the ${ }^{31} \mathrm{P}$ NMR spectrum will show a single resonance.

The reactions of aminophosphines, $\mathrm{Ph}_{2} \mathrm{PN}(\mathrm{H}) \mathrm{R}$ with $\mathrm{CpRuCl}\left(\mathrm{PPh}_{3}\right)_{2}$ afford monosubstituted [CpRuCl$\left.\left(\mathrm{PPh}_{3}\right)\left(\mathrm{PPh}_{2} \mathrm{~N}(\mathrm{H}) \mathrm{R}\right)\right]$ or disubstituted [CpRuCl$\left(\mathrm{PPh}_{2} \mathrm{~N}(\mathrm{H}) \mathrm{R}\right)_{2}$ ] complexes depending upon the stoichiometry and the reaction conditions. The reactions of $\mathrm{Ph}_{2} \mathrm{PN}(\mathrm{H}) \mathrm{R}\left(\mathrm{R}=\mathrm{Ph}, \boldsymbol{8} ; \mathrm{C}_{6} \mathrm{H}_{11}, 9\right)$ with $[\mathrm{CpRuCl}-$ $\left(\mathrm{PPh}_{3}\right)_{2}$ ] in dichloromethane in equimolar ratio at room temperature, gave $\left[\mathrm{CpRuCl}\left(\mathrm{PPh}_{3}\right)\left(\mathrm{PPh}_{2} \mathrm{~N}(\mathrm{H}) \mathrm{R}\right)\right]$ (15, $\left.\mathrm{R}=\mathrm{Ph} ; 17, \mathrm{C}_{6} \mathrm{H}_{11}\right)$ in good yield. The ${ }^{31} \mathrm{P}$ NMR spectra of complexes $\mathbf{1 5}$ and $\mathbf{1 7}$ show two doublets at $42.9,72.4 \mathrm{ppm}$ and $42.9,77.9 \mathrm{ppm}$, respectively. The chemical shifts at high fields are due to the $\mathrm{PPh}_{3}$ group whereas the aminophosphines appear at lower field. The ${ }^{2} J_{\mathrm{PRuP}}$ couplings are 42.4 and $48.5 \mathrm{~Hz}$ for complexes 15 and $\mathbf{1 7}$, respectively. In contrast, the reactions of $\left[\mathrm{CpRuCl}\left(\mathrm{PPh}_{3}\right)_{2}\right]$ with 8 and $\mathbf{9}$ in $1: 2$ molar ratio in toluene at $80-90^{\circ} \mathrm{C}$ gave disubstituted complexes of the type, $\left[\mathrm{CpRuCl}\left(\mathrm{PPh}_{2} \mathrm{~N}(\mathrm{H}) \mathrm{R}\right)_{2}\right](\mathbf{1 6}$,
$\left.\mathrm{R}=\mathrm{Ph} ; 18, \mathrm{C}_{6} \mathrm{H}_{11}\right)$ in $\sim 75 \%$ yield containing trace amount of respective monosubstituted complexes, $\left[\mathrm{CpRuCl}\left(\mathrm{PPh}_{3}\right)\left(\mathrm{PPh}_{2} \mathrm{~N}(\mathrm{H}) \mathrm{R}\right)\right]\left(\mathbf{1 5}, \mathrm{R}=\mathrm{Ph}, \mathbf{1 5} ; \mathrm{C}_{6} \mathrm{H}_{11}\right.$, 17). The ${ }^{31} \mathrm{P}$ NMR spectra of complexes $\mathbf{1 6}$ and $\mathbf{1 8}$ showed single resonances at 72.6 and $81.8 \mathrm{ppm}$, respectively. The monosubstituted complexes $\mathbf{1 5}$ and $\mathbf{1 7}$ with an excess of the corresponding ligand also afforded the disubstituted complexes $\mathbf{1 6}$ and $\mathbf{1 8}$ as shown in scheme 4. The reactions of aminobis(phosphines), $\mathrm{Ph}_{2} \mathrm{PN}(\mathrm{R}) \mathrm{PPh}_{2}$ (R = Et, $\left.{ }^{n} \mathrm{Pr},{ }^{i} \mathrm{Pr},{ }^{n} \mathrm{Bu}\right)$ with equimolar quantity of $\left[\mathrm{CpRuCl}\left(\mathrm{PPh}_{3}\right)_{2}\right]$ yielded cationic complexes, $\left[\mathrm{CpRu}\left(\mathrm{PPh}_{3}\right)\left(\mathrm{Ph}_{2} \mathrm{PN}(\mathrm{R}) \mathrm{PPh}_{2}\right)\right] \mathrm{Cl}(\mathrm{R}=\mathrm{Et}(\mathbf{1 9})$, ${ }^{n} \operatorname{Pr}(\mathbf{2 0}),{ }^{i} \operatorname{Pr}(\mathbf{2 1}),{ }^{n} \mathrm{Bu}$ (22)) in $50-60 \%$ yield (see scheme 5).

The half-sandwich ruthenium complexes were employed in the cyclopropanation reaction of styrene derivatives in the presence of diphenyldiazomethane. Interestingly, all complexes afforded 1,1,3,3-tetraphenyl cyclobutane along with cyclopropane derivatives with $\left[\mathrm{CpRu}\left(\mathrm{PPh}_{2} \mathrm{~N}\left({ }^{n} \mathrm{Bu}\right) \mathrm{PPh}_{2}\right)\left(\mathrm{PPh}_{3}\right)\right] \mathrm{Cl}$ (22) showing better selectivity in the formation of 1,1,2triphenylcyclopropane (see scheme 6). In all reactions, appreciable amounts of cyclopropanation and metathesis products, 1,2-diphenylcyclopropane and 1, 1-diphenylethene, were obtained along with 1,1,3-triphenylpropene derivatives. The variable temperature ${ }^{1} \mathrm{H}$ NMR studies have suggested that the cyclopropanation reactions in the presence of ionic complex, $\left[\mathrm{CpRu}\left(\mathrm{PPh}_{2} \mathrm{~N}(\mathrm{R}) \mathrm{PPh}_{2}\right)\left(\mathrm{PPh}_{3}\right)\right] \mathrm{Cl}$ (22) proceeds via carbene intermediate, $\left[\mathrm{CpRu}\left(=\mathrm{CPh}_{2}\right)\left(\mathrm{PPh}_{2} \mathrm{~N}(\mathrm{R})\right.\right.$ $\left.\left.\mathrm{PPh}_{2}\right)\left(\mathrm{PPh}_{3}\right)\right] \mathrm{Cl} .^{7}$

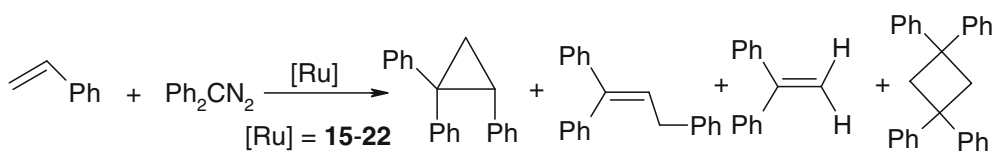

Scheme 6. Cycloproponation rections catalysed by $\mathrm{Ru}^{\mathrm{II}}$-aminophosphine complexes. 
<smiles>Pc1ccccc1OP(c1cccc(P)c1P)C1(P(c2ccccc2)c2ccccc2)Oc2ccccc2O1</smiles><smiles>[Pb]P(c1ccccc1)[C@]1(Pc2ccccc2)Oc2ccccc21</smiles>

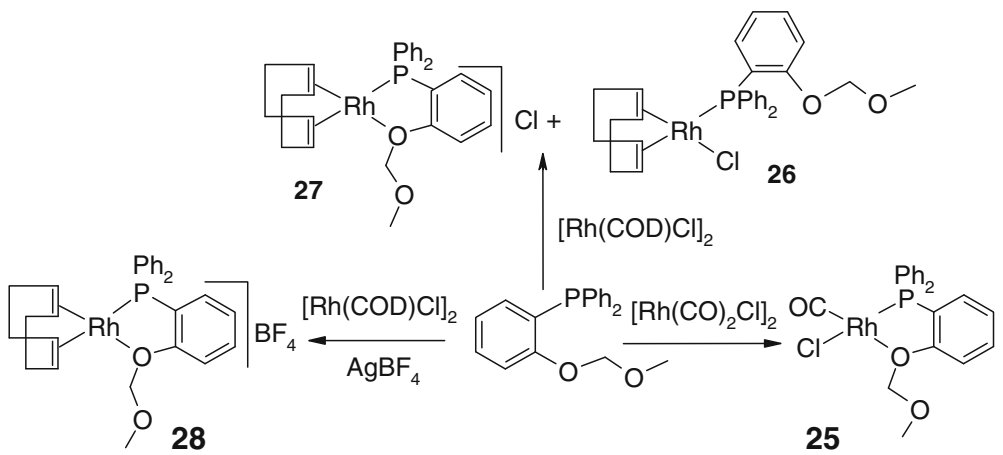

Scheme 7. Rhodium complexes of functionalized phosphine $\left\{\mathrm{Ph}_{2} \mathrm{PC}_{6} \mathrm{H}_{4}\left(\mathrm{OCH}_{2} \mathrm{OMe}-o\right)\right\}$.

\section{Phosphines with ether and alcohol functionalities}

The chemistry of phosphine ethers is interesting due to the hemilabile nature of the ether oxygen which can coordinate to soft metals along with soft-phosphorus donors. Such complexes are very useful in homogeneous catalysis. Hemilabile phosphines can coordinate to the metal centre and stabilize it in lower oxidation state and enhance the chelating possibilities through ether $\mathrm{O}$-centre. Further, the labile $\mathrm{M}-\mathrm{O}$ coordinate bond can be readily cleaved as and when it is required during the catalytic and biological processes. In view of this, we have extensively studied ${ }^{8}$ the transition metal chemistry of phosphine ethers of the type $\mathrm{Ph}_{2} \mathrm{PC}_{6} \mathrm{H}_{4} \mathrm{OCH}_{2} \mathrm{OCH}_{3}-O$ and $\mathrm{PhP}\left(\mathrm{C}_{6} \mathrm{H}_{4} \mathrm{OCH}_{2} \mathrm{OCH}_{3}-\right.$ $o)_{2}$ and phosphinophenol, $\mathrm{Ph}_{2} \mathrm{PC}_{6} \mathrm{H}_{4} \mathrm{OH}-o$. The reaction of $\mathrm{Ph}_{2} \mathrm{PC}_{6} \mathrm{H}_{4} \mathrm{OCH}_{2} \mathrm{OCH}_{3}-O$ with $\mathrm{RuCl}_{3} .3 \mathrm{H}_{2} \mathrm{O}$ gave trischelated octahedral ruthenium(III) complex, $\left[\mathrm{Ru}\left(\mathrm{Ph}_{2} \mathrm{PC}_{6} \mathrm{H}_{4} \mathrm{O}-o\right)_{3}\right]$ (23) through metathetical elimination of three equivalents of $\mathrm{CH}_{3} \mathrm{OCH}_{2} \mathrm{Cl}$, whereas the reaction with $\mathrm{CpRu}\left(\mathrm{PPh}_{3}\right)_{2} \mathrm{Cl}$ resulted in the formation of $\left[\mathrm{CpRu}\left(\mathrm{Ph}_{2} \mathrm{PC}_{6} \mathrm{H}_{4} \mathrm{O}-o\right) \mathrm{PPh}_{3}\right]$ (24).

Treatment of $\mathrm{Ph}_{2} \mathrm{PC}_{6} \mathrm{H}_{4} \mathrm{OCH}_{2} \mathrm{OCH}_{3}-O$ with rhodium(I) derivatives resulted in the formation of complexes 25-28 with phosphine ligand exhibiting both mono- and bidentate modes of coordination involving the phosphorus centre and the phenolic oxygen as shown in scheme 7 .
The reaction of $\mathrm{Ph}_{2} \mathrm{PC}_{6} \mathrm{H}_{4} \mathrm{OCH}_{2} \mathrm{OCH}_{3}-O$ with $\left[\mathrm{PdCl}_{2}(\mathrm{COD})\right]$ led to the isolation of two mononuclear complexes, $\quad\left[\mathrm{PdCl}\left(\mathrm{Ph}_{2} \mathrm{PC}_{6} \mathrm{H}_{4} \mathrm{O}-o\right)\left(\mathrm{Ph}_{2} \mathrm{PC}_{6} \mathrm{H}_{4} \mathrm{OH}-o\right)\right]$ (29) cocrystallized with phosphonium salt, $\left[\mathrm{Ph}_{2} \mathrm{P}-\right.$ $\left.\left(\mathrm{CH}_{2} \mathrm{OCH}_{3}\right) \mathrm{C}_{6} \mathrm{H}_{4} \mathrm{OH}-\mathrm{o}\right] \mathrm{Cl}(\mathbf{3 1})$ and $\left[\mathrm{Pd}\left(\mathrm{Ph}_{2} \mathrm{PC}_{6} \mathrm{H}_{4} \mathrm{O}-\right.\right.$ $o)_{2}$ ] (30) (see scheme 8) as confirmed by X-ray diffraction study. The former shows extensive hydrogen bonding interactions between the complex and the phosphonium salt. The reaction between $\mathrm{Ph}_{2} \mathrm{PC}_{6} \mathrm{H}_{4} \mathrm{OCH}_{2} \mathrm{OCH}_{3}-O$ and $\left[\mathrm{PdCl}_{2}(\mathrm{COD})\right]$ in the presence of $\mathrm{AgBF}_{4}$ afforded cationic complex [PdCl$\left.\left(\mathrm{Ph}_{2} \mathrm{PC}_{6} \mathrm{H}_{4} \mathrm{OCH}_{2} \mathrm{OCH}_{3}-O\right)_{2}\right]\left[\mathrm{BF}_{4}\right]_{2}($ 32) in quantitative yield.

A novel tetranuclear titanium complex, $\left[\left\{\left({ }^{i} \mathrm{PrO}\right)_{2}-\right.\right.$ $\left.\left.\mathrm{Ti}\left(\mu_{3}-\mathrm{O}\right) \mathrm{TiCl}\left({ }^{i} \mathrm{PrO}\right)\left(\left(\mathrm{OC}_{6} \mathrm{H}_{4}\right)_{2} \mathrm{PPh}\right)\right\}_{2}\right]$ (33) containing penta- and hexacoordinated titanium centres was

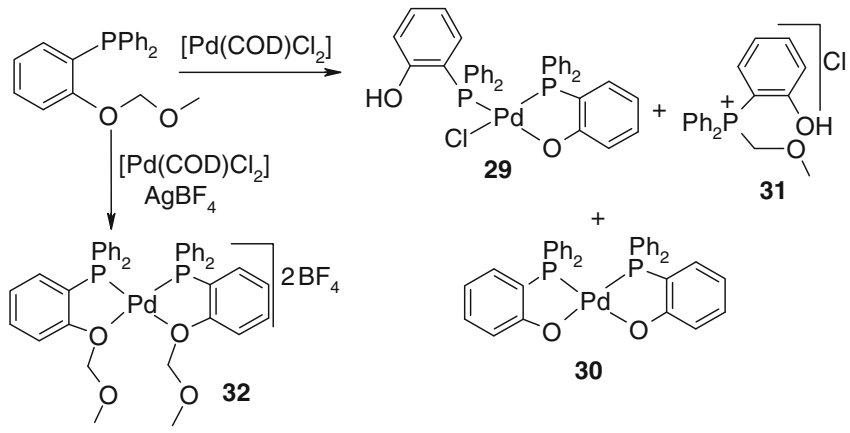

Scheme 8. Palladium complexes of functionalized phosphine $\left\{\mathrm{Ph}_{2} \mathrm{PC}_{6} \mathrm{H}_{4}\left(\mathrm{OCH}_{2} \mathrm{OMe}-o\right)\right\}$. 
obtained in the reaction of bis(o-phenol)phenylphosphine with titanium tetrachloride. The X-ray structure depicted the presence of both the bridging and the terminal isopropoxy groups. ${ }^{9}$ Although we anticipated a dimeric or tetrameric aryloxy complexes of the type $\mathbf{3 4}$ with uncoordinated phosphorus(III) centres for possible coordination to low-valent platinum metals, the preferential binding of soft-phosphorus atoms to oxophilic titanium centres to form $\mathbf{3 3}$ is due to the diphenolate substituents on phosphorus centres, which bring the $\mathrm{Ti}$ and $\mathrm{P}$ atoms in close proximity to establish Ti-P bonds.

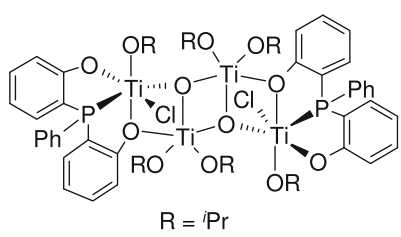

33

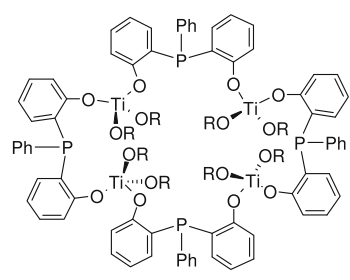

34

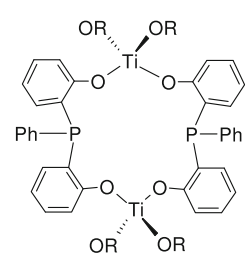

OR OR

\section{Large bite bis(phosphine) ligands}

The ligating properties of bisphosphine ligands depend to a large extent on the nature of the spacer besides the phosphorus substituents. In stereogenic ligands such as binap, restricted rotations makes them ideal ligands for asymmetric synthesis. If the bulky groups can rotate freely about a pivoting group, the induced ring strain can facilitate the dissociation of one of the metalphosphorus bonds so that a catalyst precursor may be generated. ${ }^{10}$ In such cases, the large bite angle will enhance the steric congestion around the metal centre, which favours the less sterically demanding transition state leading to selectivity in catalysis. ${ }^{11}$ In view of this, several large-bite bis(phosphine) ligands were synthesized ${ }^{12}$ and their transition metal chemistry and catalytic reactions were investigated.

Bis(2-diphenylphosphinoxynaphthalen-1-yl)methane (35) reacts with Group 6 metal carbonyls, $\left[\mathrm{Rh}(\mathrm{CO})_{2} \mathrm{Cl}\right]_{2}$, anhydrous $\mathrm{NiCl}_{2}, \quad\left[\mathrm{Pd}\left(\eta^{3}-\mathrm{C}_{3} \mathrm{H}_{5}\right) \mathrm{Cl}\right]_{2} /$ $\mathrm{AgBF}_{4}$ and $\mathrm{M}(\mathrm{COD}) \mathrm{X}_{2}$ to give the corresponding 10-membered chelate complexes $\mathbf{3 6}-\mathbf{4 2}$ as shown in scheme 9. Reaction of $\mathbf{3 5}$ with $[\mathrm{Rh}(\mathrm{COD}) \mathrm{Cl}]_{2}$ in the presence of $\mathrm{AgBF}_{4}$ afforded a cationic complex, $\quad\left[\mathrm{Rh}(\mathrm{COD})\left\{\mathrm{Ph}_{2} \mathrm{P}\left(-\mathrm{OC}_{10} \mathrm{H}_{6}\right)\left(\mu-\mathrm{CH}_{2}\right)\left(\mathrm{C}_{10} \mathrm{H}_{6} \mathrm{O}-\right)-\right.\right.$ $\left.\left.\mathrm{PPh}_{2}\right\}\right] \mathrm{BF}_{4}(\mathbf{4 3})$. Treatment of 35 with $\mathrm{AuCl}\left(\mathrm{SMe}_{2}\right)$ gives mononuclear chelate complex, $\left[(\mathrm{AuCl})\left\{\mathrm{Ph}_{2}\right.\right.$ $\left.\left.\mathrm{P}\left(-\mathrm{OC}_{10} \mathrm{H}_{6}\right)\left(\mu-\mathrm{CH}_{2}\right)\left(\mathrm{C}_{10} \mathrm{H}_{6} \mathrm{O}-\right) \mathrm{PPh}_{2}\right\}\right] \quad$ (44) as well as a binuclear complex, $\left[\mathrm{Au}(\mathrm{Cl})\left\{\mu-\mathrm{Ph}_{2} \mathrm{P}\left(-\mathrm{OC}_{10} \mathrm{H}_{6}\right)\right.\right.$ $\left.\left.\left(\mu-\mathrm{CH}_{2}\right)\left(\mathrm{C}_{10} \mathrm{H}_{6} \mathrm{O}-\right) \mathrm{PPh}_{2}\right\} \mathrm{AuCl}\right]$ (45) with ligand 35 exhibiting both chelating and bridged bidentate modes of coordination respectively (see scheme 9). The mixture of $\mathrm{Pd}(\mathrm{OAc})_{2}$ and $\mathbf{3 5}$ effectively catalyses Suzuki cross-coupling reactions of a range of aryl halides with aryl boronic acids in $\mathrm{MeOH}$ at room temperature or at $60^{\circ} \mathrm{C}$, giving generally high yields even under low catalytic loads. The cationic rhodium(I) complex, $\quad\left[\mathrm{Rh}(\mathrm{COD})\left\{\mathrm{Ph}_{2} \mathrm{P}\left(-\mathrm{OC}_{10} \mathrm{H}_{6}\right)\left(\mu-\mathrm{CH}_{2}\right)\left(\mathrm{C}_{10} \mathrm{H}_{6} \mathrm{O}-\right)\right.\right.$ $\left.\left.\mathrm{PPh}_{2}\right\}\right] \mathrm{BF}_{4} \quad(\mathbf{4 3})$ catalyses the hydrogenation of styrenes to afford the corresponding alkyl benzenes at room temperature or at $70^{\circ} \mathrm{C}$ with excellent turnover frequencies. ${ }^{13}$

\section{Diphenylether based bisphosphine and phosphino-phosphinimine ligands}

The large bite bis(2-(diphenylphosphino)phenyl)ether (DPEphos) (46) with a relatively rigid diphenyl ether backbone and containing both oxygen and phosphorus donor sites ${ }^{14}$ offers different coordination modes exhibiting rich coordination and organometallic chemistry with various metal centres. van Leeuwen and coworkers ${ }^{15}$ have extensively studied the coordination chemistry and catalytic utility of DPEphos. As part of our research interest, we have investigated the ruthenium ${ }^{16}$ and copper ${ }^{17}$ chemistry DPEphos and also catalytic hydrogenation of styrene.

The half-sandwich complexes $\left[\left(\eta^{5}-\mathrm{C}_{5} \mathrm{H}_{5}\right) \mathrm{RuCl}-\right.$ (DPEphos) $]$ (47) and $\left[\left\{\left(\eta^{6}-p \text {-cymene }\right) \mathrm{RuCl}_{2}\right\}_{2}(\mu\right.$ DPEphos)] (48) were synthesized by the reaction of bis(2-(diphenylphosphino)phenyl)ether (DPEphos) (46) with a mixture of ruthenium trichloride trihydrate and cyclopentadiene and with $\left[\left(\eta^{6}-p \text {-cymene }\right) \mathrm{RuCl}_{2}\right]_{2}$, respectively. Treatment of $\mathbf{4 6}$ with $\mathrm{cis}$ - $\left[\mathrm{RuCl}_{2}(\mathrm{dmso})_{4}\right]$ afforded $f a c$ - $\left[\mathrm{RuCl}_{2}\left(\eta^{3}\right.\right.$-DPEphos)(dmso)] (49). The dmso ligand in 49 can be substituted by pyridine, 2,2'-bipyridine, 4,4'-bipyridine and $\mathrm{PPh}_{3}$ to yield 


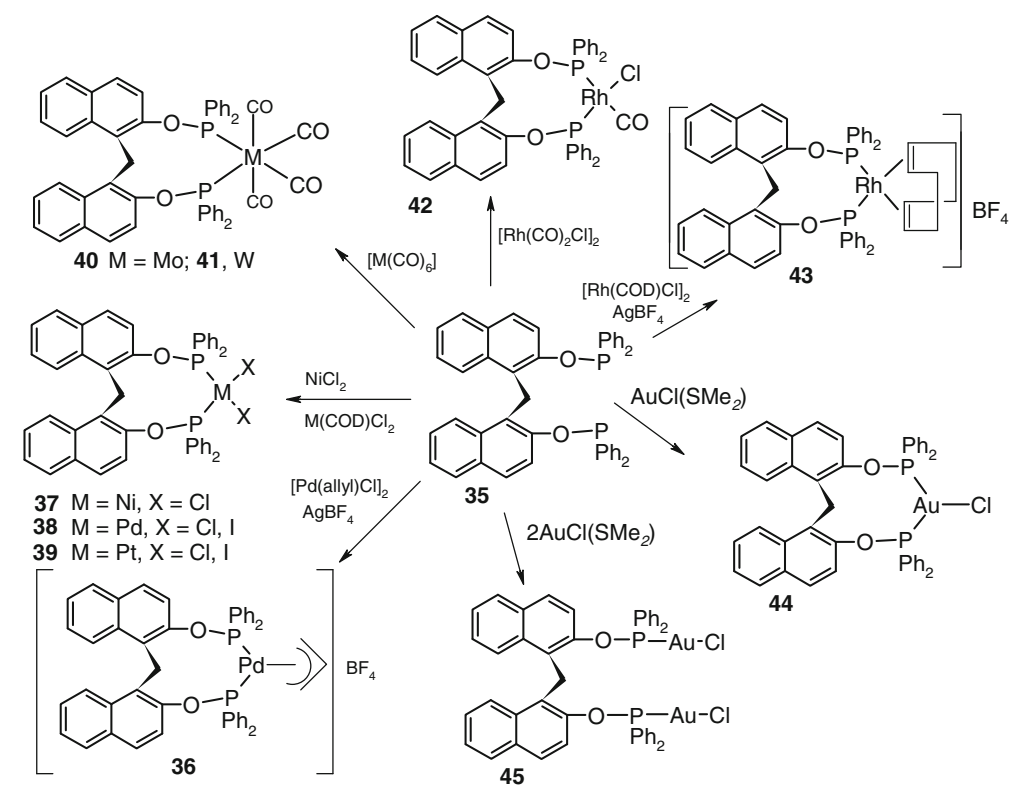

Scheme 9. Reactions of $\mathbf{3 5}$ transtion metal derivatives.

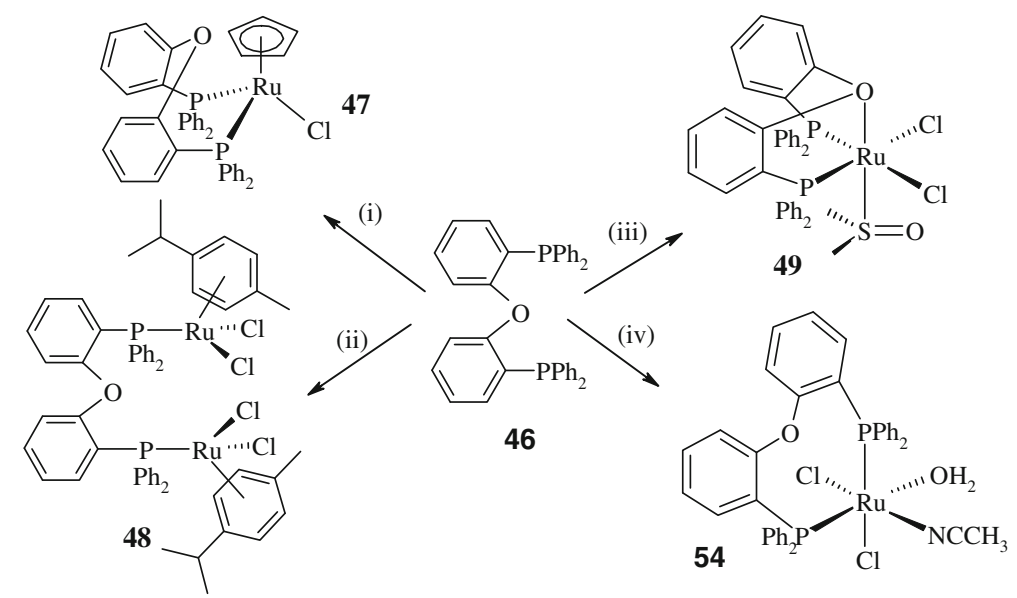

Scheme 10. Reactions of DPEphos with (i) $\mathrm{RuCl}_{3} \cdot 3 \mathrm{H}_{2} \mathrm{O}$ and $\mathrm{Cp}$ in ethanol; (ii) $\left[\mathrm{RuCl}_{2}(p \text {-cymene) }]_{2}\right.$ in $\mathrm{CH}_{2} \mathrm{Cl}_{2}$; (iii) cis- $\left[\mathrm{RuCl}_{2}(\mathrm{dmso})_{4}\right]$ in $\mathrm{CH}_{2} \mathrm{Cl}_{2}$; (iv) $\left[\mathrm{RuCl}_{2}(p \text {-cymene) }]_{2}\right.$ in $\mathrm{CH}_{3} \mathrm{CN}$.

trans,cis- $\left[\mathrm{RuCl}_{2}(\mathrm{DPEphos})\left(\mathrm{C}_{5} \mathrm{H}_{5} \mathrm{~N}\right)_{2}\right] \quad$ (50), cis,cis[ $\mathrm{RuCl}_{2}$ (DPEphos)(2,2'-bipyridine)] (51), trans,cis$\left[\mathrm{RuCl}_{2}(\mathrm{DPEphos})\left(\mu-4,4^{\prime} \text {-bipyridine }\right)\right]_{\mathrm{n}}$ (52) and mer, trans-[RuCl$\left.{ }_{2}\left(\eta^{3}-\mathrm{DPEphos}\right)\left(\mathrm{PPh}_{3}\right)\right]$ (53), respectively. Refluxing $\left[\left(\eta^{6}-p \text {-cymene }\right) \mathrm{RuCl}_{2}\right]_{2}$, with DPEphos in moist acetonitrile leads to the elimination of the $p$ cymene group and the formation of the octahedral complex cis,cis-[ $\left.\mathrm{RuCl}_{2}(\mathrm{DPEphos})\left(\mathrm{H}_{2} \mathrm{O}\right)\left(\mathrm{CH}_{3} \mathrm{CN}\right)\right]$ (54) (see scheme 10). The catalytic activity of these complexes for the hydrogenation of styrene is studied. ${ }^{17}$

\section{Iminophosphoranephosphine ether as a heterodifunctional ligand}

Partially oxidized hemilabile iminophosphoranephosphane ligand $\mathbf{5 5}$ was synthesized by treating bis[2-(diphenylphosphanyl)phenyl]ether (46) with phosphoryl azide by Staudinger reaction. ${ }^{18}$ The iminophosphorane shows both monodentate and bidentate chelating coordination modes. The platinum(II), palladium(II), and rhodium(I) complexes $\mathbf{5 6}$ a, 56b, and 57, respectively, are obtained as trans isomers as shown 


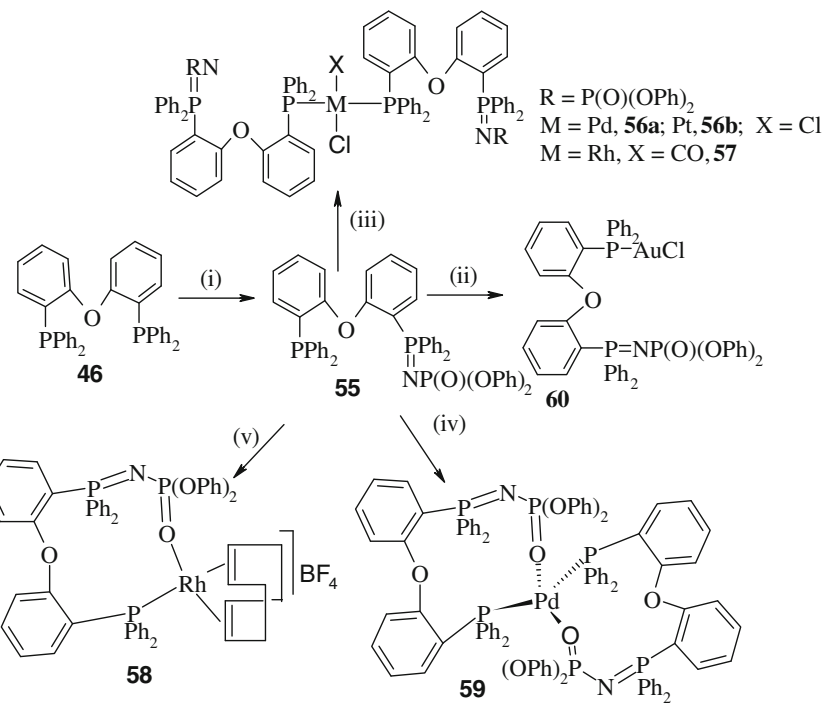

Scheme 11. Reactions of DPEphos with (i) $\mathrm{N}_{3} \mathrm{P}(\mathrm{O})(\mathrm{OPh})_{2}$ $\mathrm{CH}_{3} \mathrm{CN}$; (ii) $\mathrm{AuCl}\left(\mathrm{SMe}_{2}\right)$ in $\mathrm{CH}_{2} \mathrm{Cl}_{2}$; (iii) $\mathrm{M}(\mathrm{COD}) \mathrm{Cl}_{2}$ or $\left[\mathrm{Rh}(\mathrm{CO})_{2} \mathrm{Cl}\right]_{2}$ in $\mathrm{CH}_{2} \mathrm{Cl}_{2}$; (iv) $\mathrm{Pd}_{2} \mathrm{dba}_{3}$ in $\mathrm{C}_{6} \mathrm{H}_{6}$; (v) $[\mathrm{Rh}(\mathrm{COD}) \mathrm{Cl}]_{2}, 2 \mathrm{AgBF}_{4}$ in $\mathrm{CH}_{2} \mathrm{Cl}_{2}$.

in scheme 11 . The reaction of $\mathbf{5 5}$ with $\left[\{\mathrm{Rh}(\mathrm{COD}) \mathrm{Cl}\}_{2}\right]$ and $\mathrm{AgBF}_{4}$ produced the 11-membered macrocyclic square-planar complex 58 with iminophosphorane ligand showing chelating-bidentate mode of coordination. The cationic rhodium(I) complex $\mathbf{5 8}$ is catalytically active for the hydrogenation of olefins with a TON of $2 \times 10^{5}$ and a TOF of $6 \times 10^{5} \mathrm{~h}^{-1}$. The $\mathrm{Pd}^{0}$ complex 59, in which ligand $\mathbf{5 5}$ binds in a chelating fashion, was synthesized by the reaction of $\mathbf{5 5}$ with $\left[\mathrm{Pd}_{2}(\mathrm{dba})_{3}\right]$. The $\mathrm{Pd}^{0}$ complex $\mathbf{5 9}$ is catalytically active for Suzuki cross-coupling reactions of various aryl bromides and phenylboronic acid. A lower catalytic loading of $0.05 \mathrm{~mol} \%$ of $\mathbf{5 9}$ allows complete conversion of several aryl bromides into biaryls.

\section{Mesocyclic thioetherphosphonites}

The coordination chemistry and catalytic utility of ether and diphenyl ether-based ligands have been studied. However, the corresponding thioether-based bisphosphines or phosphonites are less extensive. Ligands combining phosphorus centres as well as sulphur centres are especially interesting. Both phosphorus and sulphur are excellent donor atoms for a wide range of transition metals, while the low ionization energy of sulphur and the existence of several lone pair of electrons (three in the case of a thiolate anion) offer the possibility of a rich sulphur-based chemistry of the complexes. To the best of our knowledge, there are no reports on cyclic thioether-aminophosphonite type of ligands, either in coordination chemistry or in catalysis. Holmes and co-workers have reported several eight-membered cyclic P, S compounds where sulphur shows coordinative interaction towards phosphorus. ${ }^{19}$ They have shown that the donor action provided by sulphur leads to an increase in coordination at phosphorus from tricoordinate to pseudopentacoordinate. However, there are no reports on coordination behaviour or catalytic activity of such ligands. It will be interesting to see the coordination chemistry of such ligands as sulphur shows coordinative tendency towards phosphorus. In this context, following mixed $\mathrm{P}, \mathrm{S}$ mesocyclic ligands were prepared and their transition metal chemistry and catalytic reactions were investigated (scheme 12).

Mesocyclic thioether-aminophosphonite ligands, $\left\{-\mathrm{OC}_{10} \mathrm{H}_{6}(\mu-\mathrm{S}) \mathrm{C}_{10} \mathrm{H}_{6} \mathrm{O}-\right\} \mathrm{PNC}_{4} \mathrm{H}_{8} \mathrm{O}(\mathbf{6 2 a})$ and $\left\{-\mathrm{OC}_{10^{-}}\right.$ $\left.\mathrm{H}_{6}(\mu-\mathrm{S}) \mathrm{C}_{10} \mathrm{H}_{6} \mathrm{O}-\right\} \mathrm{PNC}_{4} \mathrm{H}_{8} \mathrm{NCH}_{3}(\mathbf{6 2} \mathbf{b})$ are obtained by reacting $\left\{-\mathrm{OC}_{10} \mathrm{H}_{6}(\mu-\mathrm{S}) \mathrm{C}_{10} \mathrm{H}_{6} \mathrm{O}-\right\} \mathrm{PCl}(\mathbf{6 1})$ with corresponding nucleophiles. ${ }^{20}$ Similar reaction with aniline led to the isolation of nitrogen bridged bis(phosphonite) 63 in good yield. ${ }^{21}$ The ligands $62 \mathbf{a}$ and $\mathbf{6 2 b}$ react with $(\mathrm{PhCN})_{2} \mathrm{PdCl}_{2}$ or $\mathrm{M}(\mathrm{COD}) \mathrm{Cl}_{2}\left(\mathrm{M}=\mathrm{Pd}^{\mathrm{II}}\right.$ or $\left.\mathrm{Pt}^{\mathrm{II}}\right)$ to

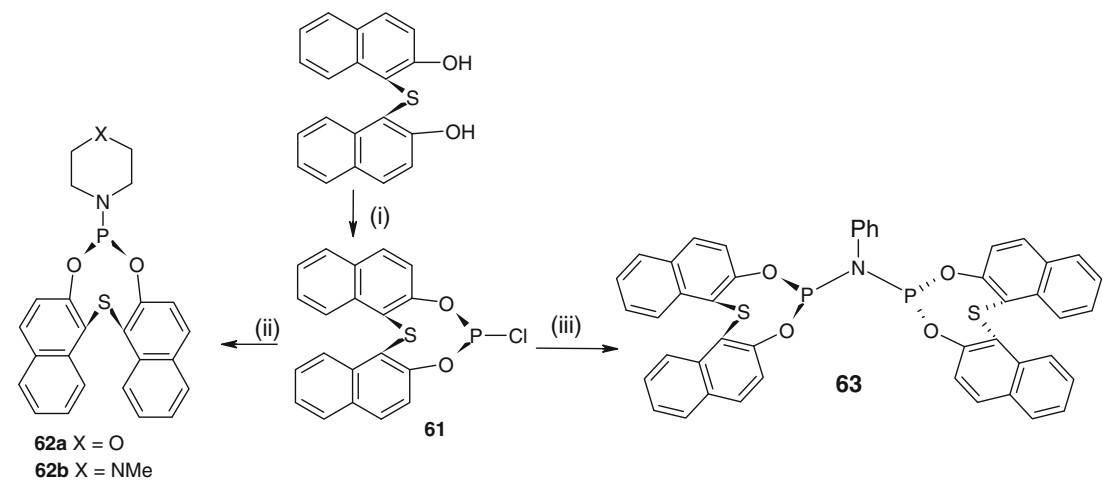

Scheme 12. (i) $\mathrm{PCl}_{3}, \mathrm{Et}_{3} \mathrm{~N}, \mathrm{DMAP},-20^{\circ} \mathrm{C}$, THF; (ii) morpholine or $N$-methyl piperazine, $0^{\circ} \mathrm{C}$, THF; (iii) $\mathrm{PhNH}_{2}, \mathrm{Et}_{3} \mathrm{~N}$, DMAP, $\mathrm{Et}_{2} \mathrm{O}$. 


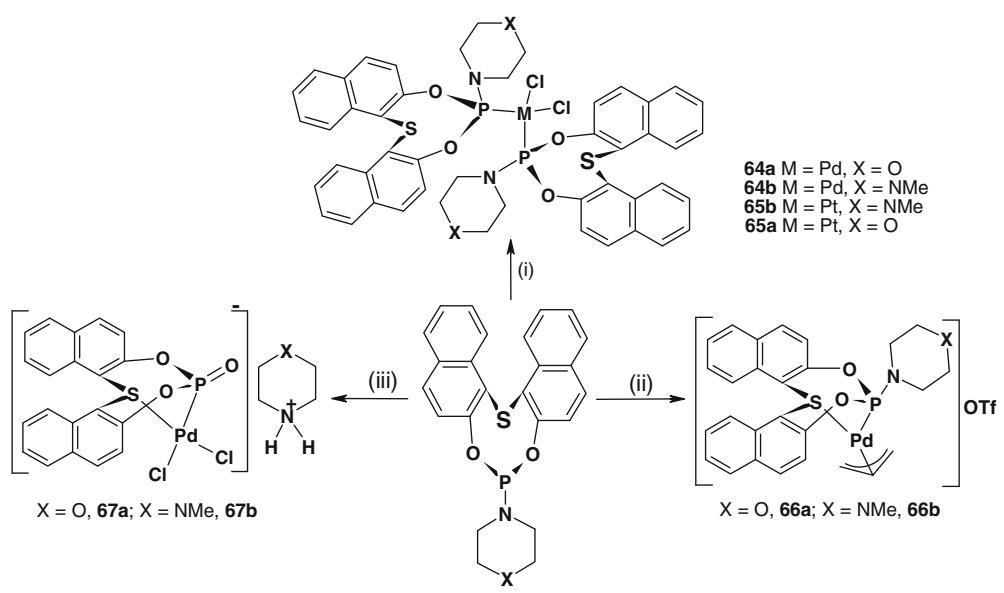

Scheme 13. (i) $\mathrm{M}(\mathrm{COD}) \mathrm{CI}_{2}, \mathrm{CH}_{2} \mathrm{CI}_{2}, 25^{\circ} \mathrm{C}$; (ii) $\left[\mathrm{Pd}\left(\eta^{3}-\mathrm{C}_{3} \mathrm{H}_{5}\right) \mathrm{CI}\right]_{2} /$ AgOTf, $\mathrm{CH}_{2} \mathrm{CI}_{2}, 25^{\circ} \mathrm{C}$; (iii) $(\mathrm{PhCN})_{2} \mathrm{PdCl}_{2}, \mathrm{H}_{2} \mathrm{O}$ (trace), toluene, $90^{\circ} \mathrm{C}$.

afford P-coordinated cis-complexes, $\left[\left\{\left(-\mathrm{OC}_{10} \mathrm{H}_{6}(\mu\right.\right.\right.$ S) $\left.\left.\left.\mathrm{C}_{10} \mathrm{H}_{6} \mathrm{O}-\right) \mathrm{PNC}_{4} \mathrm{H}_{8} \mathrm{X}\right\}_{2} \mathrm{MCl}_{2}\right](64, \mathrm{M}=\mathrm{Pd} ; 65, \mathrm{M}=$ $\mathrm{Pt})$ as shown in scheme 13. Compounds 62a and 62b on treatment with $\left[\operatorname{Pd}\left(\eta^{3}-\mathrm{C}_{3} \mathrm{H}_{5}\right) \mathrm{Cl}\right]_{2}$ in the presence of AgOTf produce the $\mathrm{P}$, S-chelated cationic complexes, $\left[\left\{\left(-\mathrm{OC}_{10} \mathrm{H}_{6}(\mu-\mathrm{S}) \mathrm{C}_{10} \mathrm{H}_{6} \mathrm{O}-\right) \mathrm{PNC}_{4} \mathrm{H}_{8} \mathrm{X}\right\} \mathrm{Pd}-\right.$ $\left.\left(\eta^{3}-\mathrm{C}_{3} \mathrm{H}_{5}\right)\right]\left(\mathrm{CF}_{3} \mathrm{SO}_{3}\right)(66 \mathbf{a}, \mathrm{X}=\mathrm{O} ; \mathbf{6 6} \mathbf{b}, \mathrm{X}=\mathrm{NMe})$. Treatment of 62a and 62 b with $(\mathrm{PhCN})_{2} \mathrm{PdCl}_{2}$ in the presence of trace amount of $\mathrm{H}_{2} \mathrm{O}$ afforded $\mathrm{P}$, S-chelated anionic complexes, $\quad\left[\left\{\left(-\mathrm{OC}_{10} \mathrm{H}_{6}(\mu-\mathrm{S}) \mathrm{C}_{10} \mathrm{H}_{6} \mathrm{O}-\right)\right.\right.$ $\left.\mathrm{P}(\mathrm{O})\} \mathrm{PdCl}_{2}\right]\left(\mathrm{H}_{2} \mathrm{NC}_{4} \mathrm{H}_{8} \mathrm{X}\right)(\mathbf{6 7 a}, \mathrm{X}=\mathrm{O}, \mathbf{6 7 b}, \mathrm{X}=$ $\mathrm{NMe}$ ), via $\mathrm{P}-\mathrm{N}$ bond cleavage. The crystal structures of most of these compounds have been determined by X-ray diffraction studies. The compound $\mathbf{6 7 a}$ is a rare and first example of crystallographically characterized anionic transition-metal complex containing a thioether-phosphonate ligand. ${ }^{20 a}$ The reactions of thioether-aminophosphonites with $\mathrm{Pt}(\mathrm{COD}) \mathrm{Cl}_{2}$ gave exclusively phosphorus coordinated cis-complexes with high $\sigma$-donor strength. Most of these palladium complexes proved to be very active catalysts for the Suzuki-Miyaura, Heck-Mizaroki carbon-carbon cross coupling and amination reactions with excellent turnover numbers (TON up to $9.2 \times 10^{4}$ using complex 67a as catalyst). ${ }^{21}$

\section{Tetra- and hexaphosphane ligands}

The chemistry of Group 11 metal complexes in their +1 oxidation state have attracted much attention due to their catalytic applications, ${ }^{22}$ role in biochemistry ${ }^{23}$ and photochemical areas. ${ }^{24}$ Also, Group 11 metals serve as versatile connecting nodes for the synthesis of supramolecular architectures through the use of dynamic coordination chemistry and weak $d^{10}-d^{10}$ metallophilic interactions ${ }^{25}$ involving rigid $N$-donor ligands, such as 4,4'-bipyridine, 4,4'-dibenzonitrile, pyrazine which can offer multi-dimensional, metalorganic materials with diverse properties. 4,4'Bipyridine has served as an effective bridging group and hundreds of interesting supramolecular architectures have been reported. ${ }^{26}$ Instances of the use of rigid linear phosphines, analogous to 4,4'-bipyridine, in the synthesis of polynuclear complexes are less extensive. ${ }^{27}$ In this context, we have designed novel tetraphosphane ligands of the type $\left\{\left(\mathrm{X}_{2} \mathrm{P}\right)_{2} \mathrm{NC}_{6} \mathrm{H}_{4} \mathrm{~N}\left(\mathrm{PX}_{2}\right)_{2}\right\}$ and explored their rich transition metal chemistry and catalytic applications. These tetraphosphanes can be compared to two 4,4'-bipyridine units fused sideways containing both electronically and sterically tunable phosphorus donor centres. A few important reactions of these ligands with transition metals are described.

The reaction of $p$-phenylenediamine with excess of $\mathrm{PCl}_{3}$ in the presence of pyridine affords $\left(\mathrm{Cl}_{2} \mathrm{P}\right)_{2} \mathrm{NC}_{6} \mathrm{H}_{4} \mathrm{~N}\left(\mathrm{PCl}_{2}\right)_{2}(\mathbf{6 8})$ in good yield. Fluorination of 68 with $\mathrm{SbF}_{3}$ produces $\left(\mathrm{F}_{2} \mathrm{P}\right)_{2} \mathrm{NC}_{6} \mathrm{H}_{4} \mathrm{~N}\left(\mathrm{PF}_{2}\right)_{2}$ (69) in moderate yield. ${ }^{28}$ The aminotetra(phosphonites), $p-\mathrm{C}_{6} \mathrm{H}_{4}\left[\mathrm{~N}\left\{\mathrm{P}\left(\mathrm{OC}_{6} \mathrm{H}_{4} \mathrm{OMe}-o\right)_{2}\right\}_{2}\right]_{2} \quad$ (70) and $p$ $\mathrm{C}_{6} \mathrm{H}_{4}\left[\mathrm{~N}\left\{\mathrm{P}(\mathrm{OMe})_{2}\right\}_{2}\right]_{2}$ (71) have been prepared by reacting 68 with appropriate amount of 2-(methoxy)phenol or methanol, respectively, in the presence of triethylamine (see scheme 14).

Interestingly, the compounds of the type 68-71 can adopt several conformations depending upon the orientation of the $\mathrm{P}-\mathrm{N}-\mathrm{P}$ skeleton with respect to the phenylene ring. Three major idealized possibilities are: (i) both phenylene and $\mathrm{P}-\mathrm{N}-\mathrm{P}$ skeletons can be coplanar; (ii) the phenylene ring can be perpendicular to the $\mathrm{P}-\mathrm{N}-\mathrm{P}$ skeletons; (iii) the phenylene and one of the 


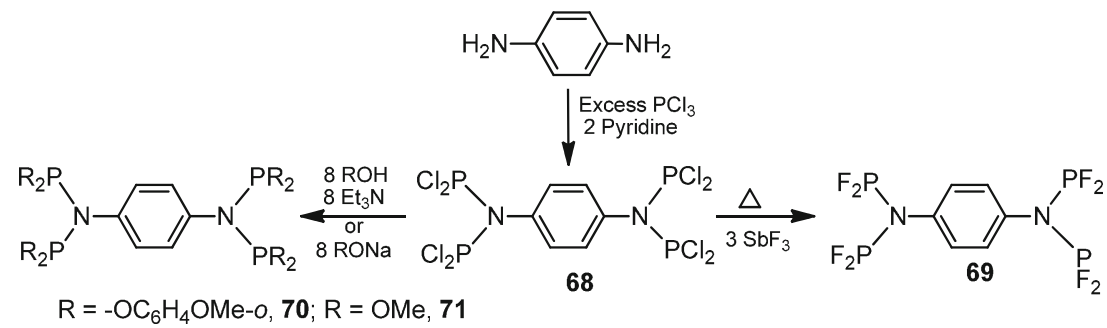

Scheme 14. Preparation of octachlorotetraphosphane and its derivatives.

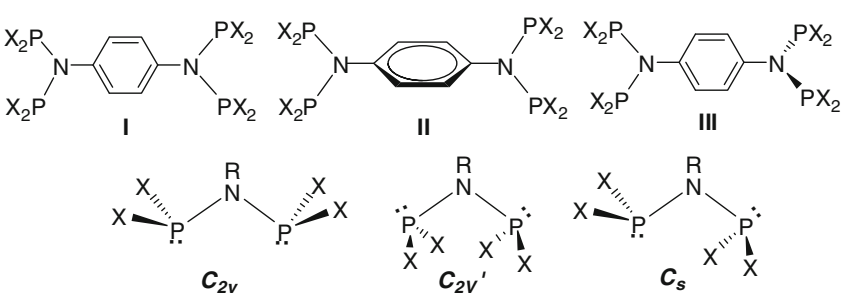

Chart 1. Possible conformations of tetraphosphane derivatives.

$\mathrm{P}-\mathrm{N}-\mathrm{P}$ skeletons can be in one plane and orthogonal to the other $\mathrm{P}-\mathrm{N}-\mathrm{P}$ skeleton. Further, the $\mathrm{P}-\mathrm{N}-\mathrm{P}$ moieties in each conformation can adopt $C_{2 V}, C_{2 V}^{\prime}$ or $C_{S}$ conformations depending on the mutual orientation of phosphorus lone pairs with respect to the phosphorussubstituents as shown in chart 1 , so there is a total of 18 possible conformations.

Reactions of $\mathbf{7 0}$ with $\left[\mathrm{M}(\mathrm{COD}) \mathrm{Cl}_{2}\right](\mathrm{M}=\mathrm{Pd}$ or $\mathrm{Pt})$ resulted in the formation of chelate complexes, $\left[\mathrm{M}_{2} \mathrm{Cl}_{4}-p-\mathrm{C}_{6} \mathrm{H}_{4}\left\{\mathrm{~N}\left\{\mathrm{P}\left(\mathrm{OC}_{6} \mathrm{H}_{4} \mathrm{OMe}-o\right)_{2}\right\}_{2}\right\}_{2}\right] \quad(\mathbf{7 2}, \mathrm{M}=$ $\mathrm{Pd} ; \mathbf{7 3}, \mathrm{M}=\mathrm{Pt}$ ). The reactions of $\mathbf{7 0}$ with four equivalents of $\mathrm{CuX}(\mathrm{X}=\mathrm{Br}$ and $\mathrm{I})$ produce the tetranuclear complexes, $\left[\mathrm{Cu}_{4}\left(\mu_{2}-\mathrm{X}\right)_{4}\left(\mathrm{NCCH}_{3}\right)_{4}-p\right.$ $\left.\mathrm{C}_{6} \mathrm{H}_{4}\left\{\mathrm{~N}\left(\mathrm{P}\left(\mathrm{OC}_{6} \mathrm{H}_{4} \mathrm{OMe}-o\right)_{2}\right)_{2}\right\}_{2}\right] \quad(\mathbf{7 4}, \mathrm{X}=\mathrm{Br} ; \mathbf{7 5}$, $\mathrm{X}=\mathrm{I}$ ) in quantitative yield as shown in scheme 15 . The molecular structures of many of these compounds are confirmed by single crystal X-ray diffraction studies. ${ }^{29}$ The weak intermolecular P...P interactions observed in 68 leads to the formation of a 2-D sheet like structure (figure 1) which is also examined by DFT calculations. The palladium(II) complex $\mathbf{7 2}$ is an efficient catalyst for the coupling of several activated and deactivated aryl bromides and chlorides with phenylboronic acid and also for the one-pot multiple carbon-carbon couplings at room temperature.

The reactions of $\mathbf{7 0}$ with $[\mathrm{Rh}(\mathrm{COD}) \mathrm{Cl}]_{2}$ in $1: 2$ and 1:1 molar ratio gave chelate complexes, $\left[\mathrm{Rh}_{4}(\mathrm{COD})_{2}-\right.$ $\left.(\mu-\mathrm{Cl})_{4}\left\{\mathrm{R}_{2} \mathrm{PN}\left(\mathrm{C}_{6} \mathrm{H}_{4}\right) \mathrm{NPR}_{2}\right\}\right]$ (76) and $\left[\mathrm{Rh}_{2}(\mu-\mathrm{Cl})_{2}\right.$ $\left.\left\{\mathrm{R}_{2} \mathrm{PN}\left(\mathrm{C}_{6} \mathrm{H}_{4}\right) \mathrm{NPR}_{2}\right\}\right]_{n}$ (77), whereas similar reaction of 71 with $[\mathrm{Rh}(\mathrm{COD}) \mathrm{Cl}]_{2}$ in dichloromethaneacetonitrile mixture gave a dinuclear complex, $\left[\mathrm{Rh}_{2} \mathrm{Cl}_{2}\left(\mathrm{CH}_{3} \mathrm{CN}\right)_{2}\left\{\mathrm{R}_{2} \mathrm{PN}\left(\mathrm{C}_{6} \mathrm{H}_{4}\right) \mathrm{NPR}_{2}\right\}\right] \quad$ (78). The reaction of $\mathbf{7 7}$ or $\mathbf{7 8}$ with $\mathrm{CO}$ afforded a dinuclear carbonyl derivative, $\left[\mathrm{Rh}_{2} \mathrm{Cl}_{2}(\mathrm{CO})_{2}\left\{\mathrm{R}_{2} \mathrm{PN}\left(\mathrm{C}_{6} \mathrm{H}_{4}\right) \mathrm{NPR}_{2}\right\}\right]$ (79) (see scheme 16). Treatment of $\mathbf{7 8}$ with two equivalents of pyrazine or 4,4'-bipyridine produced one-dimensional coordination polymers, $\left[\mathrm{Rh}_{2} \mathrm{Cl}_{2}\right.$ $\left.\left(\mathrm{C}_{4} \mathrm{H}_{4} \mathrm{~N}_{2}\right)\left\{\mathrm{R}_{2} \mathrm{PN}\left(\mathrm{C}_{6} \mathrm{H}_{4}\right) \mathrm{NPR}_{2}\right\}\right]_{n}$ (80) (figure 2) and $\left[\mathrm{Rh}_{2} \mathrm{Cl}_{2}\left(\mathrm{C}_{10} \mathrm{H}_{8} \mathrm{~N}_{2}\right)\left\{\mathrm{R}_{2} \mathrm{PN}\left(\mathrm{C}_{6} \mathrm{H}_{4}\right) \mathrm{NPR}_{2}\right\}\right]_{\mathrm{n}}(\mathbf{8 1})$, in quantitative yield. ${ }^{30}$ These polymers have the metals in conjugation with aromatic $\pi$-systems through $\mathrm{P}-\mathrm{N}-\mathrm{P}$ skeletons with $\mathrm{P}-\mathrm{N}$ bonds showing multiple bond

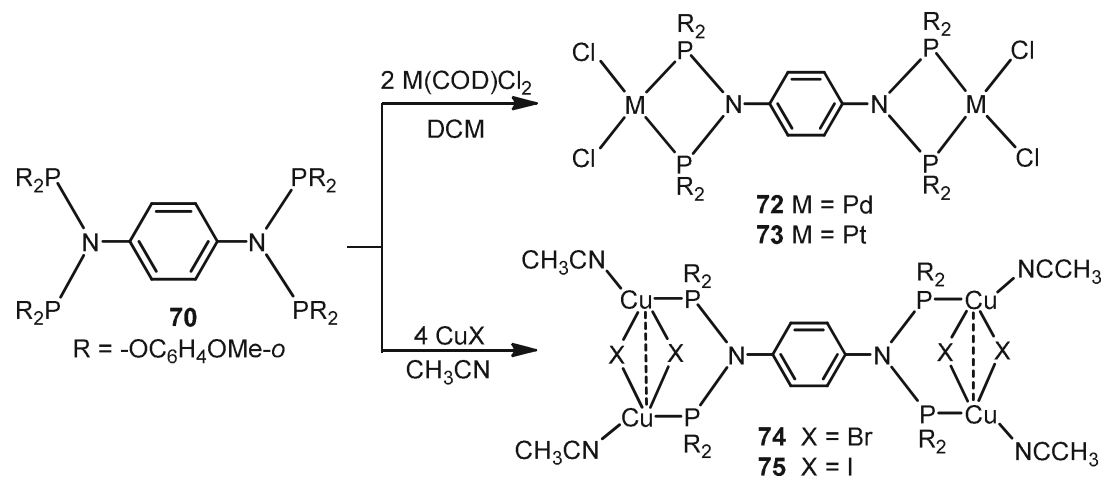

Scheme 15. Palladium, platinum and copper complexes of $\mathbf{7 0 .}$ 


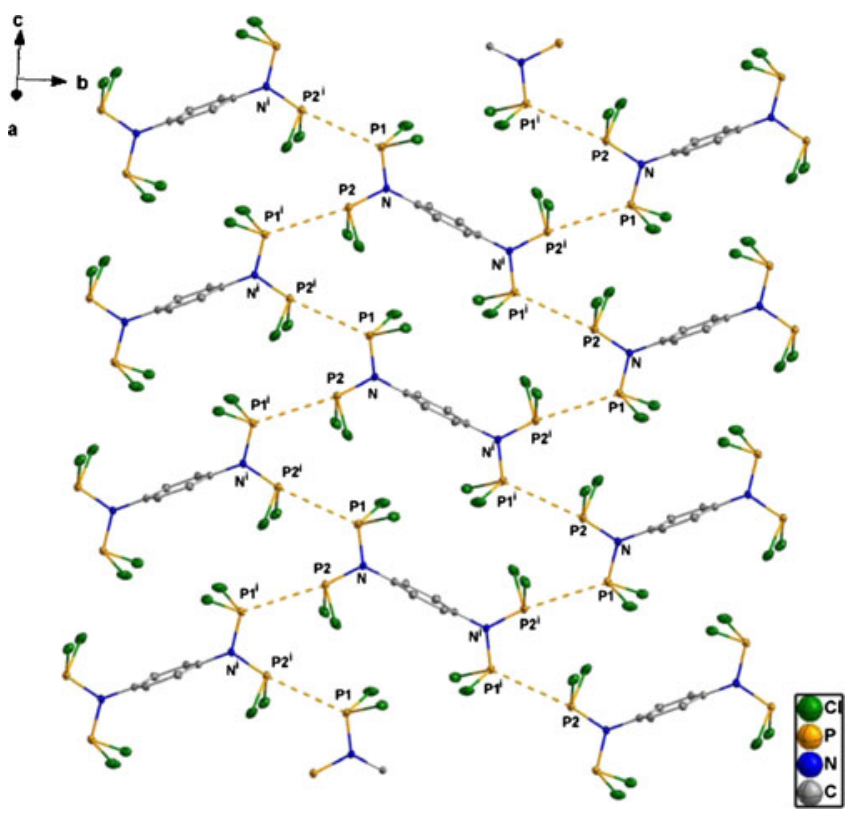

Figure 1. Octachlorotetraphosphane $(\mathbf{6 8})$ showing intermolecular P...P interactions.

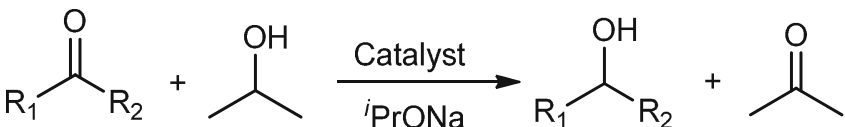

Scheme 17. Transfer hydrogenation reaction of ketones using rhodium(I)-tetraphosphane complexes 76-81.

character evinced by X-ray structure determination. By choosing appropriate redox-active metals and substituents at the P-centres it is possible to design efficient conducting polymers.

The catalytic activity of rhodium(I) complexes 7681 and some ruthenium(II) complexes ${ }^{31}$ have been investigated in transfer hydrogenation reactions (see scheme 17). Among them, the tetra metallic complex 76 appeared to be the most active precursor for the reduction of acetophenone $\left(8 \mathrm{~h}, \mathrm{TON}=199 \mathrm{~h}^{-1}\right)$ and further it was used for the reduction of ketones other than acetophenone. The reduction performed with benzophenone yielded $80 \%$ of diphenylmethanol after $24 \mathrm{~h}$ with

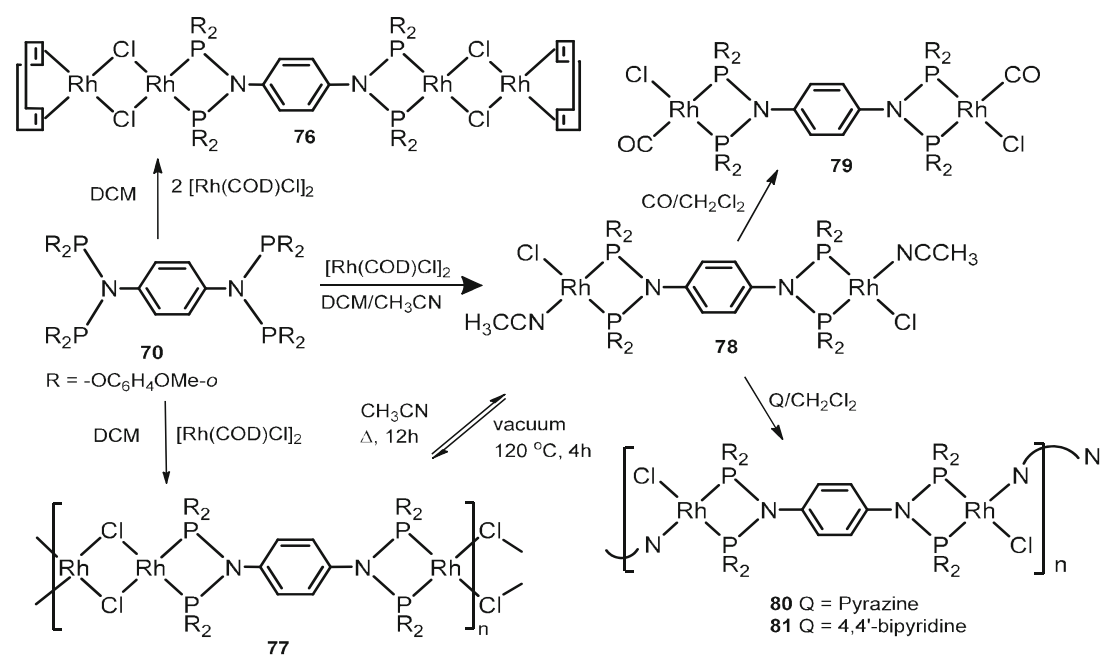

Scheme 16. Reactions of tetraphosphane 70 with rhodium derivatives.

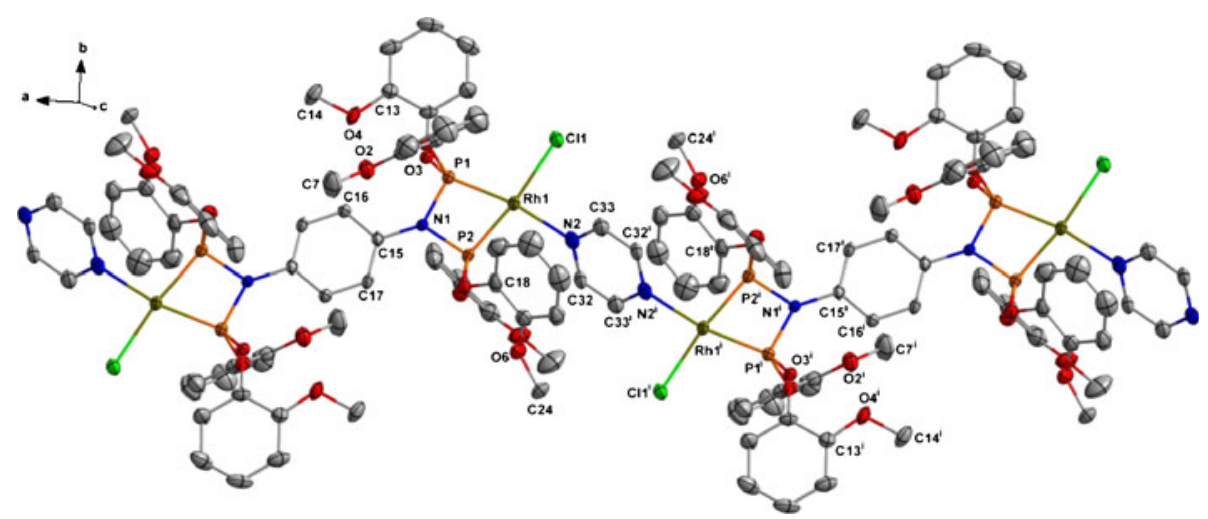

Figure 2. Molecular structure of one-dimensional $\mathrm{Rh}^{\mathrm{I}}$ zigzag coordination polymer $\left[\mathrm{Rh}_{2} \mathrm{Cl}_{2}\left(\mathrm{C}_{4} \mathrm{H}_{4} \mathrm{~N}_{2}\right)\left\{\mathrm{R}_{2} \mathrm{PN}\left(\mathrm{C}_{6} \mathrm{H}_{4}\right) \mathrm{NPR}_{2}\right\}\right]_{n}(\mathbf{8 0})$. 


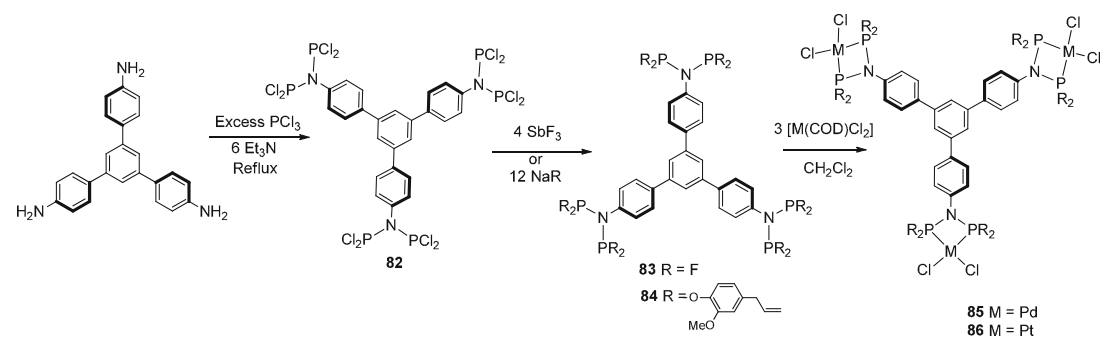

Scheme 18. Preparation and derivatization of dodecachlorohexaphosphane 82.

complex 76. The complex 76 also showed good activity in the transfer hydrogenation of six-membered cyclic ketones such as $\alpha$-tetralone and cyclohexanone but at different rates. Further, the reduction of 4-bromo acetophenone tends to proceed at significantly lower rate with low yield because of the higher mesomeric effect caused by bromide substitution.

\section{Hexaphosphanes and metallocene-based bisphosphanes}

The reaction of 1,3,5-tris (4'-aminophenyl)benzene with phosphorus trichloride in the presence of three equivalents of pyridine afforded the novel dodecachlorohexaphosphane, 1,3,5- $\mathrm{C}_{6} \mathrm{H}_{3}\left[p-\mathrm{C}_{6} \mathrm{H}_{4} \mathrm{~N}\left(\mathrm{PCl}_{2}\right)_{2}\right]_{3}(\mathbf{8 2})$ as a pale yellow crystalline solid in $20 \%$ yield. The yield has been further improved by carrying out the reaction in the presence of a strong base like triethylamine with a catalytic amount of $N, N$-dimethyl-4aminopyridine (see scheme 18). The compound $\mathbf{8 2}$ readily decomposes on exposure to air and moisture. The fluorination of $\mathbf{8 2}$ with antimony trifluoride yielded the fluoro analogue, 1,3,5- $\mathrm{C}_{6} \mathrm{H}_{3}\left[p-\mathrm{C}_{6} \mathrm{H}_{4} \mathrm{~N}\left(\mathrm{PF}_{2}\right)_{2}\right]_{3}(\mathbf{8 3})$ in good yield. The ${ }^{31} \mathrm{P}$ NMR spectrum of 82 consists of a single peak at $153.7 \mathrm{ppm}$, whereas $\mathbf{8 3}$ shows the A portion of an $\mathrm{AA}^{\prime} \mathrm{X}_{2} \mathrm{X}_{2}^{\prime}$ multiplet centred at $130.4 \mathrm{ppm}$ with $\left|{ }^{1} J_{\mathrm{PF}}\right|,\left|{ }^{3} J_{\mathrm{PF}}\right|$ and $\left.\right|^{2} J_{\mathrm{PP}} \mid$ couplings of 1246, 124 and $372 \mathrm{~Hz}$, respectively. The single crystal X-ray diffraction analysis of $\mathbf{8 2}$ showed the distorted pyramidal geometry about the phosphorus centres and a planar environment around the nitrogen centres with the sum of the angles around nitrogen almost $360^{\circ}$ in all cases. Further the bridging phenylene rings are almost perpendicular to the plane of the P-N-P skeletons. The reaction of $\mathbf{8 2}$ with 12 equivalents of 4-allyl-2-methoxyphenol in the presence of triethylamine afforded hexaphosphonite, 1,3,5$\mathrm{C}_{6} \mathrm{H}_{3}\left[p-\mathrm{C}_{6} \mathrm{H}_{4} \mathrm{~N}\left\{\mathrm{P}(\mathrm{OR})_{2}\right\}_{2}\right]_{3} \quad\left[\mathrm{R}=-\mathrm{C}_{6} \mathrm{H}_{3} \mathrm{OMe}\left(\mathrm{C}_{3} \mathrm{H}_{5}\right)\right]$ (84) in quantitative yield. Compounds 82-84 are potential hexadentate ligands and are expected to behave as simple aminobisphosphine units mimicking their coordination behaviour. In a preliminary study, the ligand $\mathbf{8 4}$ has been used for the preparation of platinum group metal complexes. Treatment of 84 with three equivalents of $\left[\mathrm{M}(\mathrm{COD}) \mathrm{Cl}_{2}\right](\mathrm{M}=\mathrm{Pd}$ or $\mathrm{Pt}$ ) in dichloromethane afforded the chelate complexes, 1,3,5- $\mathrm{C}_{6} \mathrm{H}_{3}\left[p-\mathrm{C}_{6} \mathrm{H}_{4} \mathrm{~N}\left\{\mathrm{P}(\mathrm{OR})_{2}\right\}_{2}\left(\mathrm{MCl}_{2}\right)\right]_{3}[\mathrm{R}=$ $\left.-\mathrm{C}_{6} \mathrm{H}_{3} \mathrm{OMe}\left(\mathrm{C}_{3} \mathrm{H}_{5}\right)\right](\mathbf{8 5}, \mathrm{M}=\mathrm{Pd} ; \mathbf{8 6}, \mathrm{M}=\mathrm{Pt})$ in good yield. The ${ }^{31} \mathrm{P}$ NMR spectra of complexes $\mathbf{8 5}$ and $\mathbf{8 6}$ show single resonances at 63.2 and $57.9 \mathrm{ppm}$, respectively, which are considerably shielded compared to the free ligand. The platinum complex exhibits a large ${ }^{1} J_{\mathrm{PtP}}$ coupling of $5913 \mathrm{~Hz}$, which is consistent with the proposed cis geometry around the platinum centre. $^{32}$

Ferrocenyl-phosphine ligands are versatile and are able to form complexes with transition metals in a variety of coordination geometries and oxidation states, which have proven to be efficient catalysts in homogeneous catalysis. Several ferrocenyl-phosphines have been extensively studied and have shown good catalytic activity in organic synthesis. In contrast, ferrocenylphosphonites or -phosphite derivatives are less extensive although, due to their easy preparation methods, can be an attractive alternative to ferrocenylphosphines. In view of this, we have made several bisphosphonites, phosphites and aminophosphines based on ferrocenyl framework and explored their transition metal chemistry and catalytic applications. Few of these ligands and their transition metal chemistry

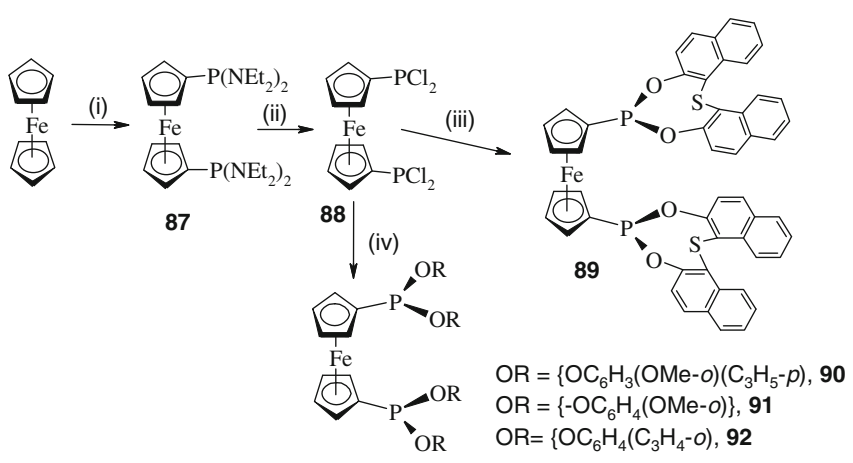

Scheme 19. (i) $1 .{ }^{n} \mathrm{BuLi}$, TMEDA; 2. $\mathrm{CIP}\left(\mathrm{Net}_{2}\right)_{2}$; (ii) $\mathrm{HCI}(\mathrm{g}), \mathrm{Et}_{2} \mathrm{O},-78^{\circ} \mathrm{C}$; (iii) Diol, $\mathrm{Et}_{3} \mathrm{~N}, \mathrm{Et}_{2} \mathrm{O}$; (iv) $\mathrm{ROH}$, $\mathrm{Et}_{3} \mathrm{~N}, \mathrm{Et}_{2} \mathrm{O},-20^{\circ} \mathrm{C}$. 


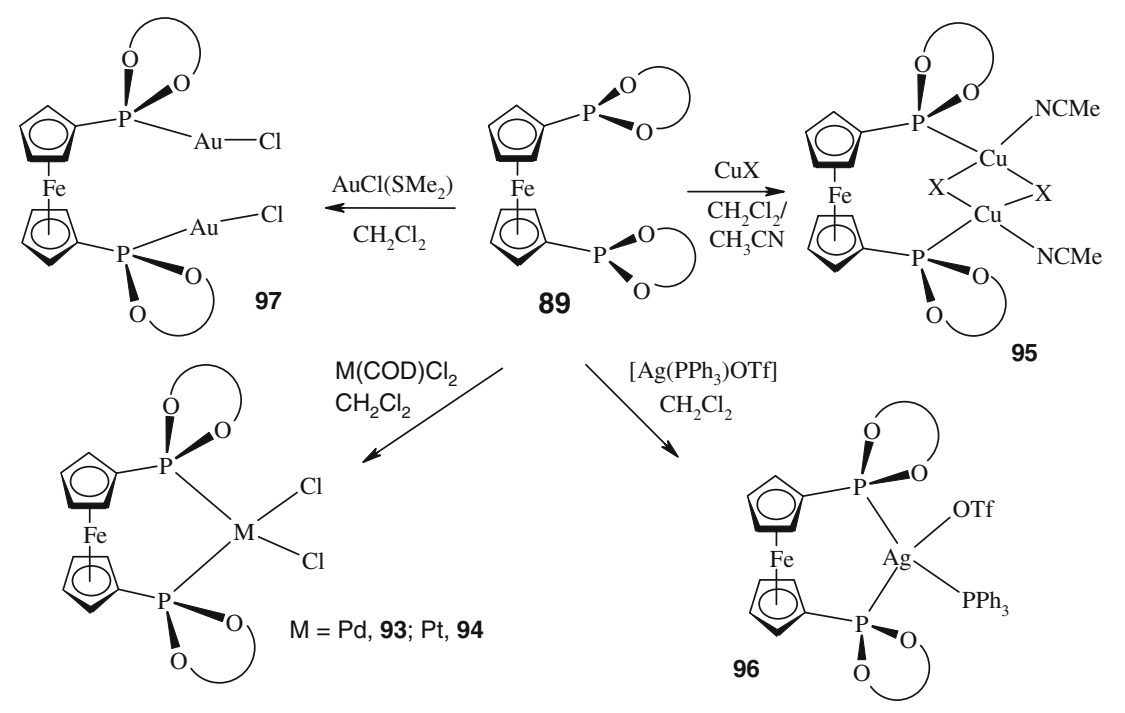

Scheme 20. Metal complexes of Ferrocenyl-phosphonite 89.

is described. The synthetic method adopted for the preparation of various ferrocenyl-phosphanes is given in scheme 19.

The chloro-precursor $\mathbf{8 8}$ readily undergoes nucleophilic substitution at phosphorus centres to form bisphosphonites of the type 89-92 in good to moderate yields. Ferrocenyl-phosphonite ligand $\mathbf{8 9}$ readily react with platinum and Group 11 metals to form interesting metal complexes (see scheme 20). The palladium complexes show good catalytic activity towards Suzuki-Miyaura cross coupling reactions. ${ }^{33-35}$

\section{Summary}

Several phosphorus based ligands ranging from simple tertiary phosphines to hexaphosphane ligands have been synthesized and their transition metal chemistry and catalytic applications have been investigated. The synthetic flexibility, easy synthetic methodology with readily accessible nucleophilic sites and the presence of three soft donor centres make the heterocyclicdiphosphanes (1- and 2) a valuable ligand system. Aminophosphines and aminobis(phosphines) form interesting ruthenium(II) compelxes and they catalyse cycloproponation reactions. Formation of 1,1,3,3-tetraphenyl cyclobutane was observed for the first time in the cycloproponation reactions.

Phosphinoethers show both mondentate and bidentate coordination modes involving $\mathrm{P}(\mathrm{III})$ and ether oxygen centres. These ligands also generate metalphenoxide bonds through metathetical elimination of methoxymethylchloride on treatment with platinum metal halide-derivatives. The reaction of bis $(o-$ phenol)phenylphosphine with $\mathrm{TiCl}_{4}$ in toluene and isoproponol yielded a novel heptacyclic tetranuclear titanium complex containing four different types of oxygen binding along with formal titanium-phosphorus bonds. Large-bite bis(phosphonite) 35 with $\mathrm{Pd}(\mathrm{OAc})_{2}$ catalyses Suzuki-Miyaura C-C coupling reactions, whereas the rhodium complex $\mathbf{4 3}$ catalyses the hydrogenation of various styrenes with excellent turnover numbers. Bis(diphenylphosphino)phenylether 46 and its partially oxidized iminophosphorane-phosphane derivative $\mathbf{5 5}$ form interesting complexes with various transition metals and the palladium(0) and rhodium(I) complexes of later show excellent catalytic activity towards Suzuki-Miyaura C-C coupling reactions and hydrogenation of styrenes and acetylenes, respectively. The mesocyclic thioether-aminophosphonites due to their flexible framework display rich coordination chemistry, especially, the anionic palladium complex 67 promotes Suzuki-Miyaura, Mizoroki-Heck coupling reactions as well as amination reactions with very high catalytic activity (TON up to $1.5 \times 10^{6}$ ). Octachlorotetraphosphane $\mathbf{6 8}$ shows intermolecular P...P interactions whose estimated strength is around -5 to $-10 \mathrm{~kJ} \mathrm{~mol}^{-1}$. Tetraphosphane derivatives form simple binuclear to tetranuclear and polynuclear metal complexes and 1D-, 2D- and 3D-coordination polymers with Group 11 metals. Tetraphosphanes in combination with pyridyl ligands could serve as efficient tectons for the generation of interesting conglomerates which might find useful applications. For the first time an efficient one-pot synthesis of a novel dodecachlorohexaphosphane is achieved in our laboratory and its preliminary reactions have been carried out. These polydentate phosphorus ligands on aromatic framework are best suited to generate polynuclear complexes with metals in close proximity to understand their 
mutual cooperativitiy, in case, such metal complexes are found suitable for homogeneous catalysis.

\section{Acknowledgements}

The majority of the work described here has been performed by my past graduate students; Drs. S Priya, R Panda, P P George, B Punji and C Ganesamoorthy. I am thankful to them for their synthetic skills and dedication. I am indebted to Prof. Joel T Mague, Tulane University, New Orleans, for X-ray structure determination. Our work was supported by the Department of Science and Technology (DST), the Council of Scientific and Industrial Research (CSIR), New Delhi, and we are grateful for their continued support.

\section{References}

1. (a) Applied homogeneous catalysis with organometallic compounds $20022^{\text {nd }}$ Edition, B Cornils, W A Herrmann (eds) (Weinheim: Wiley-VCH); (b) Miyaura N and Suzuki A 1995 Chem. Rev. 95 2457; (c) Suzuki A 1998 In: Metal catalysed cross coupling reactions, F Diederich, P J Stang (eds) (Weinheim: Wiley-VCH) p. 49 and references therein

2. (a) Balakrishna M S, Reddy V S, Krishnamurthy S S, Nixon J F and St Laurent B C T R 1994 Coord. Chem. Rev. 129 1; (b) vand der Vlugt J I, Sablong R, Mills A M, Kooijman H, Spek A L, Meetsma A and Vogt D 2003 Dalton Trans. 4690; (c) Punji B, Mague J T and Balakrishna M S 2006 J. Organomet. Chem. 691 4265; (d) Smith R C and Protasiewicz J D 2004 Organometallics 234215

3. (a) Chandrasekaran P, Mague J T, Venkateswaran R and Balakrishna M S 2007 Eur. J. Inorg. Chem. 4988; (b) Chandrasekaran P, Mague J T and Balakrishna M S 2005 Inorg. Chem. 44 7925; (c) Suresh D, Balakrishna M S and Mague J T 2008 Dalton Trans. 3272; (d) Balakrishna M S, Venkateswaran R and Mague J T 2009 Inorg. Chem. 48 1398; (e) Chandrasekaran P, Mague J T and Balakrishna M S 2009 Dalton Trans. 5478; (f) Suresh D, Balakrishna M S, Rathinasamy K, Panda D and Mobin S M 2008 Dalton Trans. 2812; (g) Balakrishna M S 2010 J. Organomet. Chem. 695 925; (h) Balakrishna M S, Suresh D, Rai A, Mague J T and Panda D 2010 Inorg. Chem. 498790

4. (a) Ganesamoorthy C, Balakrishna M S, Mague J T and Tuononen H M 2008 Inorg. Chem. 47 7035; (b) Punji B, Mague J T and Balakrishna M S 2007 Inorg. Chem. 46 10268; (c) Punji B, Mague J T and Balakrishna M S 2006 J. Organomet. Chem. 691 4265; (d) Priya S, Mague $\mathrm{J} \mathrm{T}$ and Balakrishna M S 2001 Inorg. Chem. Commun. 4 437; (e) Balakrishna M S, Panda R, Smith Jr D C, Klaman A and Nolan S P 2000 J. Organomet. Chem. 599 159; (f) Punji B, Mague J T and Balakrishna M S 2006 J. Mol. Cat. A Chem. 259 78; (g) Venkateswaran R, Mague J T and Balakrishna M S 2007 Inorg. Chem. 46 809; (h) Ganesamoorthy C, Balakrishna M S, George P P and Mague J T 2007 Inorg. Chem. 46 848; (i) Kaboudin B and Balakrishna M S 2007 Synth. Commun. 31 2773; (j) Mohanty S and Balakrishna M S 2010 J. Chem. Sci. 122137

5. Balakrishna M S, Panda R and Mague J T 2001 Inorg. Chem. 405620

6. (a) Priya S, Balakrishna M S and Mague J T 2003 J. Organomet. Chem. 679 116; (b) Priya S, Balakrishna M S, Mague J T and Mobin S M 2003 Inorg. Chem. 42 1272

7. Priya S, Balakrishna M S, Mobin S M and McDonald R 2003 J. Organomet. Chem. 688227

8. Priya S, Balakrishna M S and Mague J T 2004 J. Organomet. Chem. 6893335

9. Priya S, Balakrishna M S and Mague J T 2004 Chem. Lett. 33308

10. (a) Guo R, Lough A J, Morris R H and Song D 2004 Organometallics 23 5524; (b) Kesanli B and Lin W 2004 Chem. Commun. 2284; (c) Hölscher M, Franci ö G and Leitner W 2004 Organometallics 23 5606; (d) Wiles J A, Daley C J A, Hamilton R J, Leong C G and Bergens S H 2004 Organometallics 234564

11. Carb'o J J, Maseras F, Bo C and van Leeuwen P W N M 2001 J. Am. Chem. Soc. 1237630

12. (a) Balakrishna M S, Panda R and Mague J T 2002 J. Chem. Soc. Dalton Trans. 40 4617; (b) Balakrishna M S, Priya S and Panda R 2003 Phosphorus, Sulfur, Silicon 1781391

13. Punji B, Mague J T and Balakrishna M S 2006 Dalton Trans. 1322

14. Kamer P C J, van Leeuwen P W N M and Reek J N H 2001 Acc. Chem. Res. 34895

15. (a) Kranenburg M, van der Burgt Y E, Kamer P C J, van Leeuwen $\mathrm{P}$ W N M, Goubitz K and Fraanje J 1995 Organometallics 14 3081; (b) Zuideveld M A, Swennenhuis B H G, Boele M D K, Guari Y, van Strijdonck G P F, Reek J N H, Kamer P C J, Goubitz K, Fraanje J, Lutz M, Spek A L and van Leeuwen P W N M 2002 J. Chem. Soc. Dalton Trans. 2308

16. Venkateswaran R, Mague J T and Balakrishna M S 2007 Inorg. Chem. 46809

17. Venkateswaran R, Balakrishna M S, Mobin S M and Tuononen H M 2007 Inorg. Chem. 466535

18. Venkateswaran R, Balakrishna M S and Mobin S M 2007 Eur. J. Inorg. Chem. 1930

19. (a) Sherlock D J, Chandrasekaran A, Day R O and Holmes R R, 1997 J. Am. Chem. Soc. 119 1317; (b) Sherlock D J, Chandrasekaran A, Day R O and Holmes R R 1997 Inorg. Chem. 365082

20. (a) Punji B, Mague J T and Balakrishna M S 2006 Inorg. Chem. 45 9454; (b) Punji B, Mague J T and Balakrishna M S 2007 Eur. J. Inorg. Chem. 720

21. Punji B, Mague J T and Balakrishna M S 2007 Inorg. Chem. 4611316

22. (a) Gorin D J and Toste F D 2007 Nature 446 395; (b) Jimenez-Nunez E and Echavarren A M 2007 Chem. Commun. 333; (c) Hashmi A S K and Hutchings G J 2006 Angew. Chem. Int. Ed. 457896

23. (a) Marzano C, Pellei M, Alidori S, Brossa A, Lobbia G G, Tisato F and Santini C 2006 J. Inorg. Biochem. 100 299; (b) Pellei M, Lobbia G G, Santini C, Spagna R, Camalli M, Fedeli D and Falcioni G 2004 Dalton Trans. 2822 
24. (a) Harkins S B and Peters J C $2005 \mathrm{~J}$. Am. Chem. Soc. 127 2030; (b) Araki H, Tsuge K, Sasaki Y, Ishizaka S and Kitamura N 2005 Inorg. Chem. 44 9667; (c) Cuttell D G, Kuang S-M, Fanwick P E, McMillin D R and Walton R A 2002 J. Am. Chem. Soc. 1246

25. (a) Schmidbaur H 1995 Chem. Soc. Rev. 24 391; (b) Gimeno M C and Laguna A 1997 Chem. Rev. 97 511; (c) Puddephatt R J 2001 Coord. Chem. Rev. 216-217 313; (d) Schmidbaur H 2001 Nature 413 31; (e) Hunks W J, Jennings M C and Puddephatt R J 2002 Inorg. Chem. 41 4590

26. (a) Blake A J, Champness N R, Hubberstey P, Li W-S, Withersby M A and Schroder M 1999 Coord. Chem. Rev. 183 117; (b) Matsumoto K, Harada Y, Yamada N, Kurata H, Kawase T and Oda M 2006 Cryst. Growth Des. 6 1083; (c) Reger D L, Watson R P and Smith M D 2006 Inorg. Chem. 4510077

27. (a) Irwin M J, Vittal J J and Puddephatt R J 1997 Organometallics 16 3541; (b) Catalano V J, Malitz M A,
Horner S J and Vasquez J 2003 Inorg. Chem. 42 2141; (c) Lin R, Yip J H K, Zhang K, Koh L L, Wong K-Y and Ho K P 2004 J. Am. Chem. Soc. 12615852

28. Ganesamoorthy C, Balakrishna M S, Mague J T and Tuononen H M 2008 Inorg. Chem. 477035

29. Ganesamoorthy C, Balakrishna M S and Mague J T 2009 Inorg. Chem. $\mathbf{4 8} 3768$

30. Ganesamoorthy C, Balakrishna M S and Mague J T 2009 Dalton Trans. 1984

31. Ganesamoorthy C, Balakrishna M S and Mague J T 2009 J. Organomet. Chem. 6943390

32. Sowmya R, Ganesamoorthy C, Mobin S M and Balakrishna M S 2011 Dalton Trans. 405841

33. Punji B, Mague J T and Balakrishna M S 2007 Inorg. Chem. 4610268

34. Balakrishna M S and Mague J T 2007 Organometallics 264677

35. Sowmya R, Balakrishna M S and Mague J T 2012 (Unpublished results) 